University of Louisville

ThinkIR: The University of Louisville's Institutional Repository

6-1948

\title{
A study of one hundred and forty King's Daughters Home for Incurables applicants served by Family Service Organization, January 1, 1946-December 31, 1947.
}

Elizabeth Conder Lewis

University of Louisville

Follow this and additional works at: https://ir.library.louisville.edu/etd

Part of the Social Work Commons

\section{Recommended Citation}

Lewis, Elizabeth Conder, "A study of one hundred and forty King's Daughters Home for Incurables applicants served by Family Service Organization, January 1, 1946-December 31, 1947." (1948). Electronic Theses and Dissertations. Paper 2007.

https://doi.org/10.18297/etd/2007

This Master's Thesis is brought to you for free and open access by ThinkIR: The University of Louisville's Institutional Repository. It has been accepted for inclusion in Electronic Theses and Dissertations by an authorized administrator of ThinkIR: The University of Louisville's Institutional Repository. This title appears here courtesy of the author, who has retained all other copyrights. For more information, please contact thinkir@louisville.edu. 


\title{
UNIVERSITY OF IOUISVIIIE
}

A STUDY OF ONE HUNDRED AND FORTY KING'S DAUGHTERS HOME FOR INCURABLES APPLICANTS SERVED BY FAMIIY SERVICE ORGANIZATION JANUARY 1, 1946 - DECEMBER 31, 1947

\author{
A Dissertation \\ Submitted to the Faculty \\ Raymond A. Kent School of Social Work \\ In Partial Fulfillment of the \\ Requirements for the Degree \\ of Master of Science in Social Work
}

by

Elizabeth Conder Lewis

1948 
IIAME OF STUDENT: Elizabeth Conder Lewis

TITLE OF THESIS: A Study of One Hundred and Forty King's Daughters Home for Incurables Applicants Served by Family Service Organization January 1, 1946-December 31, 1947.

APPROVED BY THE READING COMMITTEE COMPOSED OF THE FOLIOWING MEMBERS:

Howell V. Williams

Mathilda Mathisen

NAME OF DEAN: Howell V. Williams

DATE: June II, 1948 
IIST OF TABLES .......... Page INTRODUCTION . . . . . . . . . . . 2 Chapter

I. ADMISSION POLICY OF KING'S DAUGHTERS HOME FOR INCURABLES . . . . . . 6

II. ADMISSIONS . . . . . . . . . II

Age on Admission ....... 13

Marital Status....... 14

Residence ........ 16

Religion ........ 17

Diagnosis . . . . . . 18

Social Agency Contacts. . . . . 21

Precipitating Causes for

Application. . . . . . 22

Living Arrangements. . . . . 24

Attitudes about Entrance to

the Home ....... 26

Source of Application. .... 28

Number of Services on the Cases. 29

Time between Application and

Admission ...... 36

III. WITHDRAWALS . . . . . . . 39

Age at Time of Withdrawal ... . 4I

Marital Status .........4 41

Residence. . . . . . . .. 42

Diagnosis. . . . . . . . 44

Reasons for Withdrawal. ... . 45

Social Agency Contacts. . . . . 47

Precipitating Causes for

Application. . . . .. 48

Iiving Arrangements. . . . . 49

Attitudes about Entrance to

the Home. . . . . . 50

Referral Source ........ 51

Number of Services on the Case. 52 
IV. REFUSALS . . . . . . . . 58

Age at Time of Refusal . . . . 59

Residence ......... 61

Reasons Applicants were Found

Ineligible ....... 61

Social Agenoy Contacts.... 65

Precipitating Causes for

Application ........665

Iiving Arrangements. . . . . 66

Attitudes about Entrance to

the Home : *. . * 67

Number of Services :. : . 69

v. THE WAITING LIST ......... 79

Age of Applicants ...... 81

Marital Status ........82

Diagnosis . . . . . . . 82

Residence ......... 83

Social Agency Contacts..... . 84

Source of Application .... 85 Precipitating Causes for

Application. . . . . . . 88

Living Arrangements. . . . . . 88

Attitudes about Entrance to the

Home . . . . . . . 89

Services on the Waiting Iist . . 89

VI. COMCLUSIONS AND RECOMMENDATIONS . . 91

APPENDIX Schedule Used In Study . . .97

BIBLIOGRAPHY. . . . . . . IO2 
Table

1. Age of Patients on Admission by Sex .... 13

2. Age of Patients on Admission by Marital Status .............. 15

3. Marital Status at Time of Admission by Sex . . 15

4. Admissions by Residence and Sex . . . . 17

5. Admissions by Religion .......... 18

6. Diagnoses of Patients by Age and.Sex .... 19

7. Patients Identified by Social Service Exchange by Sex................... 21

8. Precipitating Causes for Application by Sex . .23

9. Living Arrangements by Sex... . ... 25

10.. Patient's Attitudes about Entrance by Sex . . .26

11. Relative's Attitude about Patient's Entrance to the Home ... . . . . . . . . . . 27

12. Referral Source . . . . . . . . 28

13. Services to the Applicant by Family Service .. 30

14. Contacts by Family Service with the Referral Source ................ 30

15. Services by Family Service to the Relatives . . 31

16. Contacts Between Agency Staff Members . . . 32

17. Contacts by Family Service with the Home . . .32

18. Contacts by Family Service with Community Resources ................ 33 
19. Humber of Services . . . . . . . 35

20. Time Between Application and Admission . 37

21. Iiving Arrangements between Application and Admission ............... 38

22. Agency or Persons making Iiving Arrangements38

\section{Withdrawals}

23. Age of Applicants at Time of Withdrawal by Sex. ................ . 42

24. Age of Lpplicant at Time of Withdrawal by Marital Status and Sex. . . . . ... . 42

25. Residence . . . . . . . . 43

26. Diagnosis of Withdrawals by Sex . . . . 44

27. Reasons Given for Withdrawal . . . . 4 46

28. Social Service Exchange Information by Sex. 47

29. Precipitating Causes for Application by Sex 49

30. Iiving Arrangements of Withdrawals . . . .50

31. Attitudes of Applicant About Entrance to the Home. . . . . . . . . . . 51

32. Relative's Attitudes about Applicant Entering the Home ......... 52

33. Referral Source .......... 53

34. Service by Family Service to the Applicant. .............. 53

35. Service by Family Service to the Relatives . 54

36. Contacts By Family Service with the Referral ............. . . 54

37. Contacts by Family Service with the Home . .55 
38. Contacts by Family Service with Community Resources ............ . . 55

39. Number of Services . . . . . . . . 56

\section{Refusals}

40. Age of Applicant at Time of Refusal by Sex.60

41. Marital Status . . . . . . . . 60

42. Residence ..............61

43. Reasons Applicant was found Ineligible for Care . . . . . . . . . . 63

44. Refusals Identified by Social Service Exchange . . . ........ . 65

45. Precipitating Causes for Application by Sex................ 66

46. Iiving Arrangements . . . . . . . 67

47. Attitudes about Entrance to the Home . . 68

48. Attitudes on the Part of the Relatives in regard to the Applicant's Entering the Home . . . . . . . . . 69

49. Source of Application . . . . . . . 70

50. Services given by Family Service to Applicant . . . . . . . . . . . 71

51. Services to Relatives ........ . 72

52. Contacts by Family Service with the ReFerral Source . . . . . . . . 73

53. Contacts by Family Service with the Home. .75

54. Contacts by Family Service with Community Resources ............. . 76

55. Contacts between Agency Staff Hembers . . . 77 vil 
56. Number of Services ........ 78

\section{The Waiting Iist}

57. Age of Applicants on Waiting List . . . 81

58. Marital Status of Applicants on Waiting Iist ............... 82

59. Diagnosis of Applicants on Waiting Iist by Sex and Age ........... 83

60. Referral Source of Waiting Iist Group . . 85

61. Precipitating Causes for Application . . 88

62,. Living Arrangements . . . . . . . 89

63. Applicant's attitude Toward Entering the Home . . . . . . . . . . .90

64. Attitudes of Relatives lloward Applicant Entering Home . . . . . . . .90 
IITRODUCTION 


\section{INTRODUCTION}

\section{Purpose of the Study}

Dre to the resignation of Miss Nettie Smith, a board member of The King's Daughters Home for Incurables, Iouisville, Kentucky, who was paid on a part time basis to do social work for the Home, the board members requested help from the Community Chest in finding someone to continue the work that Miss Smith had been doing for the Home. Due to the shortage of medical social workers in the community, the Community Chest suggested that the board request the ramily Service Organization to continue with the services which Miss Smith had been performing. 1

After discussions between both Family Service Organization and the King's Daughters Home Board and with the help of Miss Mathilda Mathisen, Director of Medical Social Work, Kent School of Social Work, it was decided that Family Service would handle all applications coming to the Home beginning January 1,1946 and would continue with this service for a demonstration period of one year. ${ }^{2}$

This period has extended at the present time to a little over two years. Family Service was interested in having a study made which would sum up what this two year de-

1 Personal Interview with Esther Taylor, Family Service Organization Executive.

2 Ibid. 
monstration has show and which would help point the way for the future. It was for this purpose that this study was made.

\section{Method}

With the aid of Miss Esther Taylor and Miss Mathilda Mathisen, a tentative siohedule was constructed. This schedule was used for a sampling of ten of the cases in the total group, after which certain additions were made to the schedure. 3

The plan at first was to use all the one hundred and forty cases handled by Family Service during the two year period for only certain factors on the schedule, and a sampling of cases for the other points. However, after determining the time limit for collecting the full schedule from one case, it was decided that the entire one hundred and forty cases could be used, and the full schedule would be employed for all the cases.

All data for the study was collected through this schedule from the one hundred and forty cases. This number represented the entire group of King's Daughters Home for Incurables applicants served by Family Service during the two Jear period.

These one hundred and forty applicants were studied in 
groups. The groups were determined by their disposition-1) those admitted to the Home, 2) those refused admission to the Home because of ineligibility, 3) those who withdrew their applications and 4) those who were on the waiting list for the Home.

Data was collected about age; case number; sex; residence; marital status; religion; social service exchange information; disposition of case -- whether admitted, refused, withdrawn, or waiting--; diagnosis; precipitating causes for application; attitudes about entrance to the Home on the part of the applicant and on the part of the family of the applicant; source of intake; number of services performed by Family Service to the applicant, to the relatives of the applicant; number of contacts by Family Service with the referral, with the Home, with community resources, and the contacts between different members of the staff at Family Service; and the period between application and the disposition of the case.

At first it was felt important to collect this data in relation to all the groups. This was done but in the later analysis of the data, the factors which did not seem particularly significant were not included in the completed study.

As much as was possible the information kept by the 
5.

Home was used a check for accuracy with the material secured through the Family Service records. However, only the applicants in the admissions group could be checked, for the Home had information only on those admitted to the Home. Only the data concerning age, religion, marital status and diagnosis could be secured from the Home files, as this was the only information which doincided with the topics presented in the schedule. 
CHAPTER I

ADMISSION POLICY OF KIHG'S DAUTHTERS HOME FOR ITCURABLES 
ADMISSIONS POLICY OF KING'S DAUGHTERS HOME FOR INCURABLES

The Home for Incurables in Jouisville is a non-sectarian institution for the care of chronically ill persons. It is owned and operated by the Kentucky Branch of The King's Daughters and Sons. It is maintained for those persons who may never be entirely cured of their physical disease or disability.

The Home receives its support from members of the King's Daughters and Sons throughout the state as well as from an annual appropriation from the state of Kentucky and from patients in the Home who are able to pay for their care. The largest share of funds, however, is raised in the annual Community Chest Red Feather Campaign. For this reason the Home finds it desirable to admit more city applicants than it does applicants who come from the county and state. As nearly as possible, the admissions are kept in proportion to the amount of funds contributed by city and state.

The Home accepts any applicants after they reach the age of eighteen provided they pass the physical examination by the Home's physician. Applicants with the diagnosis of cancer, epilepsy, mental 1llness, diabetes, mental defectiveness, senility and diseases which are not incurable are ineligible for care at the Home. Applicants 
8

who need too great nursing care and those who are incontinent are ineligible. Persons addicted to drugs cannot gain admission. Reasons for refusal because of these different diagnoses vary. Cancer patients, mentally ill, mentally defective and senile patients are thought to need too much care and attention to be kept in the Home. With the relative freedom which the patients have, the mentally ill might tend to disrupt this. It is believed by the Home that the mentally defective and senile patients require more nursing care than the Home is equipped or wishes to give. The cancer patient, too, needs too much care and usually the course of the disease leads to death. Diabetics and epileptics are not admitted because of the expense of the medicine which must be administered in treatment. Too, the diet which the diabetic needs is of added expense for the Home. Since the Home is a place for persons with an incurable disease, patients with diseases not incurable are ineligible for care at the Home. Religion, too, is a factor considered by the Home. Even though it is a non-sectarian institution, there are more Protestants accepted than any other religion. Due to the provision for the Priests to hold Mass, it is felt best by the Home to keep the Catholics as close together as possible. If, however, there is no vacancy in the rooms occupied by the Catholics, persons of this religions 
faith are not turned down by the Home. There is a chapel in the Home, and the religious needs are cared for by Ministers of various denominations.

The Home, however, in spite of these things previously mentioned does consider each individual application from the standpoint of the urgency of the need. The Home has an admissions committee which is a sub-committee of the King's Daughters Home for Incurables board of directors. This committee has the responsibility of studying the social worker's recommendation on the individual application, after which the admissions committee makes the final deafsion as to admittance. In unusual instances the admissions committee discusses the situation with the board of directors. However the admissions committee has authorization to admit applicants without going through this procedure.

The maximum charge of care at the Home was \$55. monthly, but was raised to $\$ 60$. However, persons who are unable to pay anything are also eligible for care. Anything which can be offered by the patient or his family is acceptable by the Home. If the patient has in his possession any real estate, money, insurance or any other property, it is required that this be turned over to the Home for his care there. Wo distinction is made between patients 
who are receiving free care, nor does this factor play a part in the admission of the patient. At all times patients are considered in the order in which their applications appear on the waiting list.

If the patient, while staying in the Home acquires any money, real estate, insurance or other income, he must sign this over to the Home to remain there. If he should later become dissatisfied with the Home and should want to leave, the balance of the money is given back to him upon his departure. Patients who leave the Home of their own accord may later be proved ineligible if they wish to return. If they leave due to improvement of their condition and with the recommendation of the Home, they may later return when their disease becomes worse. Howezer, it is necessary for them to reapply and wait their turn on the waiting list. If the Home finds that the patient is not adjusting to care there, after the trial period, the Home may ask the patient to leave.

The physical set-up of the Home makes it possible for more women to enter than men. The ratio for this is sixtyfour to thirty six. The reason for this is due to the fact that more women than men apply for care there. 
CHAPTER II

ADNISSIONS 
CHAPPER II

\begin{abstract}
ADMISSIONS
During the entire period studied, there were 45 patients who were admitted to the Home. Twenty-six of these were admitted in 1946 and the other 19 in 1947. Eleven of these had made application to the Home before 1946. Fifteen of those accepted in 1946 were admitted during the first six months of the year. In the first six months of 1947, there were only 6 admissions. This would indicate that there were more vacancies the early part of 1946 than there were in 1947. During the two year period studied, Family Service kept a waiting list. When a vacancy occurred the agency was notified by the Home. Contact was made with the applicant at the top of the list and upon completion of examination, interviews, and other necessary procedures, the patient was admitted. This has kept the Home operating at its full capacity of one hunared patients as completely as possible. Phis benefitted the patient just as well as the Home, for most of the applicants had made only temporary arrangements with relatives, friends, or nursing homes.

The ratio of men to women patients in the Home is thirty six to sixty four. This would seem to hold true in relation to those admitted in the two year period.
\end{abstract}


There were 15 males admitted in comparison to 30 females. In 1946 there were 9 males admitted and 17 females. In 1947 there were 6 males and 13 females.

\section{Age on Admission}

The ages of the patients in the Home varied from 18 to 89. However, the largest number of admissions fell in the age group from 60 to 69. there were 25 admissions in this grouping--over half of the total admissions for the two year period. Nineteen were women and six were men.

\section{TABLE 1}

AGE OF PATIENTS ON ADNISSION BY SEX

\begin{tabular}{c|c|c|c}
\hline Age & Male & Female & Total \\
\hline $18-19$ & 2 & - & 2 \\
$20-29$ & 2 & 1 & 3 \\
$30-39$ & - & - & - \\
$40-49$ & 2 & 1 & 3 \\
$50-59$ & 2 & 4 & 6 \\
$90-69$ & 4 & 9 & 13 \\
$70-79$ & 2 & 10 & 12 \\
$80-89$ & 1 & 5 & 6 \\
Total & 15 & 30 & 45 \\
\hline
\end{tabular}

As show in Table I, the only place the men outmumbered 
or equaled the women was in the grouping from 18 to 49 years. The ratio here was six to two.

The Home's admission policy does not include any one under the age of eighteen. There were no patients above the age of eighty nine. The Home does allow patients to be admitted above this age, however, providing they pass the examination by the physician employed by the Home.

\section{Marital Status}

The majority of patients at time of admission were widowed. This might indicate one of the main reasons for applications being made to the Home. When the spouse has passed away and the children of the patient have their own families to rear and take care of, an elderly and ill person in the home can be a burden that the children sometimes do not feel they can bear. Ihis can precipitate any number of negative feelings both on the part of patient and family. I'his is one of the things that the social case worker has to face and in turn has to be capable of giving help to the patient and his family in understanding and working through these feelings. The next largest number of admissions was in the single group which seems again to bear out the point that those 
TABIE 2

AGE OF PATIENTS ON ADMISSION BY MARITAI STATUS

\begin{tabular}{c|c|c|c|c|c|}
\hline Age & Single & Married & Widowed & Divorced & Total \\
\hline $18-19$ & 2 & - & - & - & 2 \\
$20-29$ & 3 & - & - & - & 3 \\
$30-39$ & - & - & - & - & - \\
$40-49$ & 2 & - & 1 & - & 3 \\
$50-59$ & 1 & 2 & 3 & - & 6 \\
$60-69$ & 2 & 2 & 6 & 3 & 13 \\
$70-79$ & 3 & - & 9 & - & 12 \\
$80-89$ & 1 & - & 4 & 1 & 6 \\
Total & 14 & 4 & 23 & 4 & 45 \\
\hline
\end{tabular}

TABLE 3.

MARITAI STATUS AP TIME OF ADMISSION BY SEX

\begin{tabular}{l|c|c|c|}
\hline Marital Status & Male & Female & Total \\
\hline Single & 7 & 7 & 14 \\
Married & 2 & 2 & 4 \\
Widowed & 4 & 19 & 23 \\
Divorced & 2 & 2 & 4 \\
$\quad$ Total & 15 & 30 & 45 \\
\hline
\end{tabular}

persons who are alone most frequently make application to the Home. 
- With the capacity of the Home greater for women than for men, the only variation by sex in admissions for the two year period in marital status as shown in Table 3, was in the widowed group. When women are widowed it is harder for them to make their way than it is for men. Women, too, are used to a more protected environment than are men. Women, because of this may find it easier to make application and enter a Home.

\section{Residence}

As was explained in Chapter I, the admissions of Louisville residents are greater than those from the county $^{1}$ and the state. ${ }^{2}$ Three different waiting lists were kept by Family Service. Before a county or state applicant could be admitted there had to be no one remaining on the city waiting list. No state applicant could enter when there was someone on the county waiting list. Table 4, however indicates that there were not enough county applications to fill their quota. Consequently, these vacancles were filled by applicants from the state.

1 "County" is used to mean in Jefferson County but not in Jouisville.

2 "State" is used to mean in Kentucky but outside of Iouisville, or Jefferson county. 
TABLE 4

ADMISSIONS BY RESIDENCE AND SEX

\begin{tabular}{l|c|c|c}
\hline Residence & Male & Female & Total \\
\hline City & 11 & 25 & 36 \\
County & - & 2 & 2 \\
State & 4 & 3 & 7 \\
$\quad$ Total & 15 & 30 & 45 \\
\hline
\end{tabular}

It should be clarified, however, that if there are a number of women on the city waiting list and no men on the city waiting list and a vacancy occurs for a man, a county or a state male would fill this vacancy before a city woman. Ihis is due to the set-up of the Home in relation to male and female patients. A woman could not go into the men's room where the vacancy occurred.

Religion

As was explained in the first chapter, the Home accepts more Protestants than any other denomination. The Home does accept other sects, but in a limited number. Living quarters are arranged in order that the Catholics can be kept in a seperate room. Ithis enables the Priest to hold Mass in the room. I'his arrangement is not always possible, and Catholics are placed in other rooms when there is no vacancy in the room for Catholics. 
The fact that more Protestants were accepted than any other religion is shown in the following table.

\section{TABLE 5}

ADMISSIONS BY RELIGION

$\begin{array}{lc}\text { Religion } & \text { Number } \\ \text { Protestant } & 34 \\ \text { Catholic } & 8 \\ \text { Greek Orthodox } & 1 \\ \text { Other } & 2 \\ \quad \text { Total } & 45\end{array}$

Diagnosis

The findings in regard to diagnoses indicated that the greatest number of patients entered due to paralysis. The paralyses were due to hemoplegia, injury or poliomyetitis with the degree of disability varying from very slight to almost total disability. Entrances due to heart conditions, arthritis and orthopedic conditions were the next highest in diagnoses. Whe heart conditions included arteriosclerosis, hypertension and rheumatic heart. The orthopedic conditions were breaks or fractures of the hip, pelvis or shoulder. In some cases it was a combination of two of these. As shown in Table 6 these admissions were in the age grouping from 60 to 89. 
Those classified in the "Other" column consisted of only one patient in each grouping. There was one diagnosis of spinal meningitio, post-encephalitis, muscular dystrophy, amputation of both legs due to vericose veins, a semi-invalid and two patients with blindness; unless blindness is accompanied by some other disabling disease, those applicants are not admitted. In one case the blindness was accompanied by atonic colon and a crippled foot, and in the other case it was with locomotor ataxia. Some of the patients classified in Pable 6 had as many as two and three different diagnoses. In each case the diagnosis which was felt to be most crippling and disabling was chosen for use in the table.

TABIE 6

DIAGNOSES OF PATIENTS BY AGE AND SEX

\begin{tabular}{|c|c|c|c|c|c|c|c|c|c|c|c|c|}
\hline \multirow[t]{2}{*}{ Age } & \multicolumn{2}{|c|}{ Arthritis } & \multicolumn{2}{|c|}{ Paralysis } & \multicolumn{2}{|c|}{ Orthopedic } & \multicolumn{2}{|c|}{ Cardiac } & \multicolumn{2}{|c|}{ other } & \multicolumn{2}{|c|}{ Total } \\
\hline & $M$ & $F$ & M & $F$ & M & $F$ & $\mathrm{M}$ & $\mathrm{F}$ & $M$ & $F$ & M & $F$ \\
\hline $18-19$ & - & - & 1 & - & - & - & - & - & 1 & - & 2 & - \\
\hline $20-29$ & 1 & - & 1 & 1 & - & - & - & - & - & - & 2 & 1 \\
\hline $30-39$ & - & - & - & - & - & - & - & - & - & - & - & - \\
\hline $40-49$ & - & - & 1 & 1 & - & - & - & - & 1 & - & 2 & 1 \\
\hline $50-59$ & 1 & - & - & 3 & - & - & - & - & 1 & 1 & 2 & 4 \\
\hline $60-69$ & - & 4 & 3 & 3 & - & 1 & 1 & 1 & - & - & 4 & 9 \\
\hline $70-79$ & - & 1 & 1 & 2 & - & 2 & 1 & 3 & - & 2 & & 10 \\
\hline $80-89$ & - & - & 1 & 1 & - & 3 & - & - & - & 1 & 1 & 6 \\
\hline \multicolumn{2}{|c|}{ Total 2} & 5 & 8 & בוב & - & 6 & 2 & 4 & 3 & 4 & 15 & 30 \\
\hline
\end{tabular}


In working with patients suffering from these diseases it would seem quite important to have a social worker trained to understand these illnesses and what they can mean to the patient. With the greatest number falling in the paralytic, arthritic and cardiac group these are the most important to understand. The trained social worker, particularly the medical social worker, has built up a body of knowledge and understanding of the implications of the above diagnoses. With the understanding of the physical side of the illness as well as how it affects the patient emotionally; the social worker is better equipped for working with the patient and in turn can give him more understanding of his disease and the particular feelings which the disease arouses in him. With the medical knowledge which the social worker possesses, she can help to eliminate and alleviate unneeessary worry which the patient might have in regard to his disease. All of this in turn can help to bring about a happier and better adjusted patient. Knowing that he has someone accessible who understands and is interested in him can mean a great deal to the ill person. the social worker can also help the family of the patient by giving them interpretation of the patient's illness, and by stressing the importance 
of their keeping in contact with the patient, can again aid the patient.

\section{Social Agency Contacts}

More than half of the patients or their families were known to various social agencies in the past. Not all of them were relief agencies. Several of the patlents were known to more than one or two social agencies. Since more than half of the patients or their families had sought service, it might be concluded that problems were existing in their home prior to their making application for care at the Home.

\section{PABLE 7}

PATIENTS IDENTIFIED BY SOCIAL SERVICE EXCHANGE BY SEX

\begin{tabular}{l|c|c|c}
\hline \hline Patients & Male & Female & Total \\
\hline Identified* & 8 & 20 & 28 \\
Not Identified & 7 & 10 & 17 \\
Total & 15 & 30 & 45 \\
\hline
\end{tabular}

Persons listed by the Social Service Exchange as having been known to Social Agencies.

Legal Aid identified five, Jurenile Court and Visiting Nurse Association each knew four. The other listings were in Health, Child Welfare, Child Guidanco, American Red Cross and group work agencies.

Twenty of the patients were known to two relief agen- 
cies, the Hunicipal Bureau of social Service and the State Division of 0Id Age Assistance. Seven of the patients or their families were known previously to the framily Service Organization. The majority of these were service cases.

\section{Precipitating Uauses for Application}

As shown in Iable 8, the precipitating causes for the patient making application to the Home varied greatly. Not considering the medical diagnosis, the greatest cause was relatives being unable to take care of the patient. The reasons why the relatives could not give care were many. Some of them were due to crowded conditions in the home. An elderly and ill person only added to this, and the families did not feel that they could carry this added responsibility. In other cases the family was not financially able to care for the patient. In some instances the family who had formerly been able to care for the patient, found themselved unable to continue due to a flare-up in handicap of the applicant. Some of them felt the patient would receive better care in the Home than he would staying on with them. The relatives themselves were children, parents, spouses, siblings, cousins, aunts and uncles.

The next greatest cause for applications was the pat- 
ient's inability to care for himself financially. With the high cost of nursing care, it is extremely hard for a person to continue to pay for his care indefinitely, unless he has a substantial income. Even though the patient is active with 01d Age Assistance, the grant is rarely sufficient to meet his entire expenses. The only two places available to the indigent and chronically ill patient in Iouisville and Jefferson County are The King's Daughters Home and the Home for the Aged and Infirm in Shively, Kentucky. Ihis might explain one of the reasons for the long waiting lists which both of these Homes have.

TABLE 8

PRECIPITATING CAUSES FOR APPIICATION BY SEX

\begin{tabular}{l|c|cc}
\hline \hline Causes & Male & Female & Total \\
\hline $\begin{array}{l}\text { Relatives Unable } \\
\text { to Care }\end{array}$ & 7 & 11 & 18 \\
Housing & 3 & 4 & 7 \\
Couldn't keep House & - & 3 & 3 \\
Financial & 4 & 7 & 11 \\
Other & 1 & 5 & 6 \\
Total & 15 & 30 & 45 \\
\hline
\end{tabular}

Those patients grouped under the "Other" column in Table 8 included two people whose reasons for entering the Home could not be determined; one patient who was dis- 
satisfied with care in the nursing home where she was ataying; one, whom friends had been caring for but could no longer continue to do so; and one person who really had no desire to enter the Home but who was persuaded to do so by persons not connected with the Home or Family Service.

\section{Iiving Arrangements}

At the time the application was made, most of the applicants were found to be living with their families. Even though the patient was living with a distant relative, it was still considered a family; for the applicant was at that time a part of a family group. The next largest group was found to be staying in nursing homes. Two of the patients were paying for their own expenses in the nursing home. The care of the applicants was being paid for by relatives, in six of the cases. One was being cared for in the nursing home by an old age assistance grant, one with a combination of old age assistance and his own finances, and one by a combination of his finances and help given by a relative.

One of these persons had been in Louisville General Hospital nine months. After the acute state of the disease was over, the hospital was ready to release the patient. Due to his chronic illness there was no place for him to go, so application was maad to the Home, and the 
patient was transferred from the hospital to the Home upon gaining admission. The other patient also considered in this column had been in a private hospital for the past several years financed through the company where she formerily worked. She was also moved from the hospital directly to the Home upon gaining admission.

\section{TABLE 9}

IIVING ARRANGEMEINTS BY SEX

\begin{tabular}{l|c|c|c|}
\hline Iiving Arrangements & Male & Female & Total \\
\hline Alone & 1 & 3 & 4 \\
With Family & 9 & 16 & 25 \\
With Friends & 2 & 2 & 4 \\
In Nursing Home & 2 & 8 & 10 \\
In Hospitals & 1 & 1 & 2 \\
$\quad$ Total & 15 & 30 & 45 \\
\hline
\end{tabular}

Many of the patients were living with their families at the time of the application. 'this is one place where the social case worker can be of help both to the family and to the applicant. 'there is always the possibility of the family members feeling guilty over the institutional placement of a relative. 'the case worker can be of help in giving them an understanding of how the Home operates, and how the patient can benefit from an institutional placement. The social worker can also in turn help the 
patient with his or her feelings about placement. Assurance that he isn't being put out of his home, but that the best thing is being done for him is very important to the patient. It is extremely important that he does not feel rejected by his family. With the social worker present to help both the patient and his family with this, there is less opportunity for these feelings to be aroused or to be misunderstood by the patient.

\section{Attitudes about Entrance to the Home}

By far the majority of persons admitted to the Home wanted to enter. Is is pointed out that the data in llable 10 on attitudes about entrance sometimes came from only one interview. The patient usually told the case worker that he either wanted or did not want to enter; sometimes a person might say just the exact opposite of what he feels.

TABIE 10

PATIENTS ATIITUDES ABOUT ENTRANCE BY SEX

\begin{tabular}{l|c|c|c}
\hline Patients Attitudes & Male & Female & Total \\
\hline Wanted to enter & 7 & 23 & 30 \\
Did not want to enter & - & 3 & 3 \\
Ambival ent & 2 & - & 2 \\
Saw no other way out & 1 & 2 & 3 \\
Other & - & 1 & 1 \\
Unknown & 5 & 1 & 6 \\
Total & 15 & 30 & 45 \\
\hline
\end{tabular}


Consequently, it is important to know the person fairly well before true attitude can be determined. However, there must have been some positive feeling towand entrance on the part of the patient or more resistance to entrance would have been found. One person who stated that she did not want to enter did so because some of the people in the community thought the Home was the perfect place for her. She entered the Home against her own will and the advice of the Family Service worker. She later had to leave the Home because she was unable to adjust.

Included in the "Other" column of Table 10 was one patient who was so afraid that his family was trying to get rid of him, that it was impossible for him to express his feelings one way or the other.

\section{TABLE 11}

RELATIVE'S APIITUDE ABOUT PAPIENTS ENTRANGE TO HOME

Attitude

Favorable

Ambivalent

Unknown

other

Total
Total

34

1

8

2

45

The attitude: of relatives were also considered important in relation to the patient entering the Home, 
since this helped to influence the patient's adjustment to the Home after entrance.

Included in the "Other" column was one patient who had no relatives and a patient whose relative's only wish seemed to be to get rid of the Patient.

Source of Application

For the most part the referral for application came through relatives as is shown in Table 12. However, there were referrals from other sources. The agencies making the referrals were Kentucky Crippled Childrens' Commission, Municipal Bureau of Social Service, St. Vincent de Paul Society and the Municipal Housing Commission. The Bureau referred two applicants and the Crippled Children's Commission referred three. Included in the "Other" column was a lawyer, a doctor and a police officer.

TABLE 12

REFERRAL SOURCE

Source

Total

Relatives

25

Agencies

7

Friends

6

Self

2

Ministers

2

Other

Total 
Number of Services on the Cases

It was felt to be important to ascertain how much time was spent by Family Service in admitting a patient to the Home. Inoluded in services were such things as personal interviews, talephone calls, letters and visits made in connection with a particular case. It was decided to classify the contacts and separate the totals into services to the applicant, services to the relatives, contacts with referral in regard to what happened on the case or else the use of a referral as a resource, contacts with community resources, contacts with the Home in relation to a case, and the contacts on a case between workers on the staff of Family Service.

As shown in lable 13, the largest number of applicants. had only one contact with the soclal worker. Hour of those who had no contact with the worker were state applicants, and it was impossible for the worker to talk with them before entrance.

After the patient was admitted, if he was making a good adjustment to the Home there was no further contact. Some of the case workers, however, did do a follow-up interview after the patient had entered the Home even though there was no particular request for this from the Home. One of the patients with whom there was no contact by the social worker either before or after admission left the 
TABLE 13

SERVICES TO THE APPIICANI BY HANIIY SERVICE

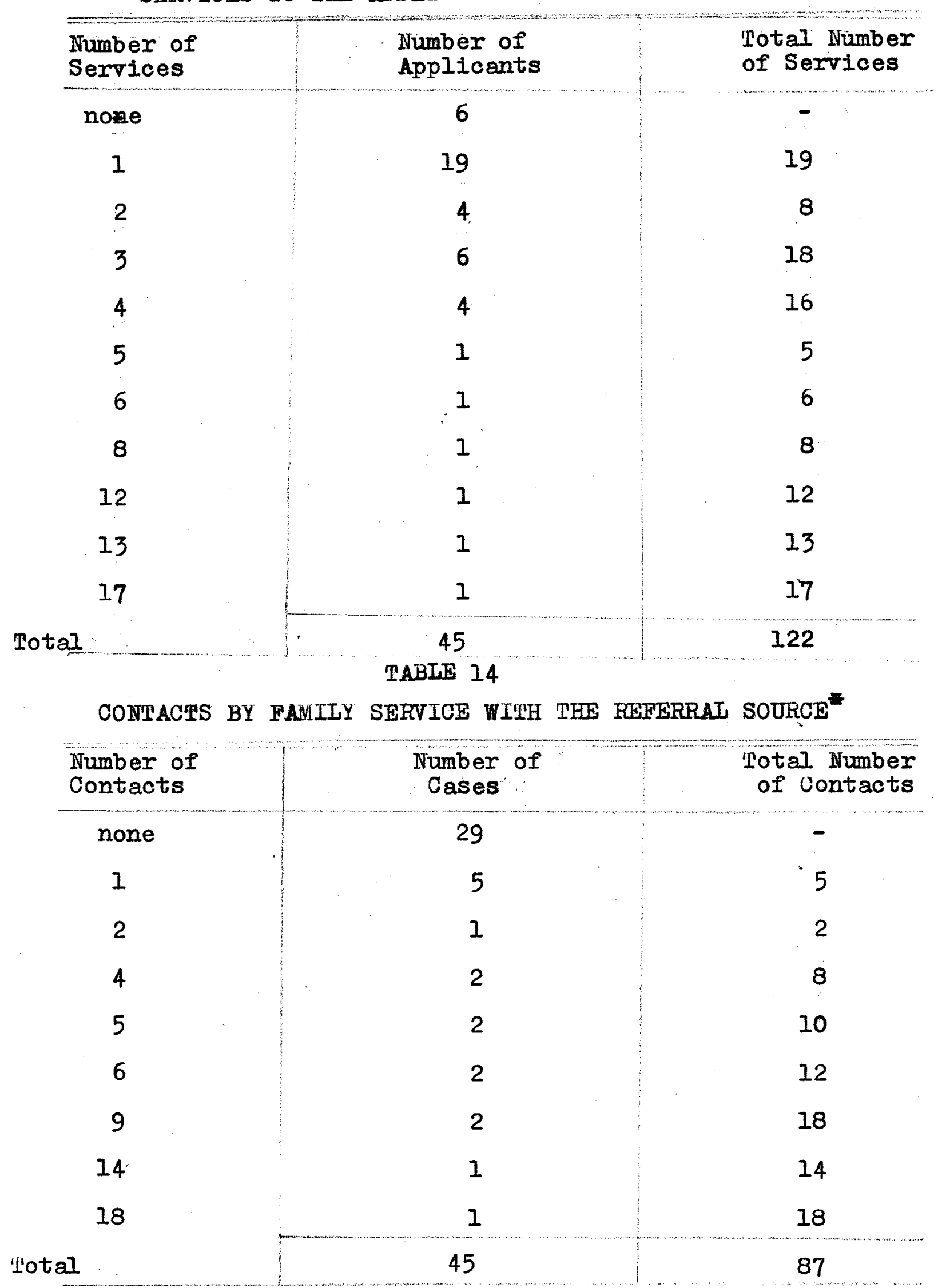

* Relatives who made referrals are not included in this table, but are included in table 15 
Home of his own accord soon after entrance. Had the social worker been able to see and talk with the patient, this might possibly have been avoided.

IABLE 15

SERVICES BY HAMILY SEHVICE TO KEIAUIVES

\begin{tabular}{|c|c|c|}
\hline Number of Services & Number of Cases & $\begin{array}{l}\text { Total Number ot } \\
\text { Services }\end{array}$ \\
\hline None & 8 & - \\
\hline 1 & 3 & 3 \\
\hline 2 & 5 & 10 \\
\hline 3 & 5 & 15 \\
\hline 4 & 4 & 16 \\
\hline 5 & 1 & 5 \\
\hline 6 & 3 & 18 \\
\hline 7 & 2 & 14 \\
\hline 8 & 1 & 8 \\
\hline 10 & 1 & 10 \\
\hline 11 & 4 & 44 \\
\hline 12 & 3 & 36 \\
\hline 13 & 1 & 13 \\
\hline 14 & 1 & 14 \\
\hline 15 & 1 & 15 \\
\hline 16 & 1 & 16 \\
\hline 25 & 1 & 25 \\
\hline Total & 45 & 262 \\
\hline
\end{tabular}


32

TABLE 16

CONIACHS BE'LWEEN AGBNCY STAFF MEMBERS

\begin{tabular}{c|c|r}
\hline $\begin{array}{c}\text { Number of } \\
\text { Contacts }\end{array}$ & $\begin{array}{c}\text { Number of } \\
\text { Cases }\end{array}$ & $\begin{array}{r}\text { Total Number } \\
\text { of Contacts }\end{array}$ \\
\hline none & 24 & - \\
1 & 8 & 8 \\
2 & 8 & 16 \\
4 & 2 & 8 \\
5 & 1 & 5 \\
6 & 1 & 6 \\
7 & 1 & 7 \\
\hline
\end{tabular}

IABLE 17

CONMACTS BY FAMIIY SERVICE WITH HOME

\begin{tabular}{c|c|c}
\hline $\begin{array}{c}\text { Number of } \\
\text { Contacts }\end{array}$ & $\begin{array}{c}\text { Number of } \\
\text { Cases }\end{array}$ & $\begin{array}{r}\text { Total Number } \\
\text { of Contacts }\end{array}$ \\
\hline 1 & 1 & 1 \\
2 & 8 & 16 \\
3 & 6 & 18 \\
4 & 5 & 20 \\
5 & 4 & 20 \\
6 & 6 & 36 \\
7 & 4 & 28 \\
8 & 3 & 24 \\
9 & 3 & 27 \\
10 & 2 & 20 \\
11 & 1 & 11 \\
15 & 1 & 15 \\
21 & 1 & 21 \\
\hline & 45 & 257 \\
\hline
\end{tabular}


Contacts with the Home were relative to the applicants diagnosis, financial status, living arrangements, and other significant information secured by Family Service through interview with the applicant. Contacts were continued with the Home in some cases where special arrangements had to be made for entrance. Contact was made with the Home in relation to a follow-up interview and in the case of a patient having a hard time adjusting; there were numerous contacts between Family Service and the Home.

TABLE 18

\begin{tabular}{c|c|c}
\multicolumn{1}{c|}{ CONTACTS BY FAMIIY SERVICE WITH COMMUNITY RESOURCES } \\
\hline $\begin{array}{c}\text { Number of } \\
\text { Contacts }\end{array}$ & $\begin{array}{c}\text { Number of } \\
\text { Cases }\end{array}$ & $\begin{array}{r}\text { Total Number } \\
\text { of Contacts }\end{array}$ \\
\hline none & 10 & - \\
1 & 9 & 9 \\
2 & 11 & 22 \\
3 & 3 & 9 \\
4 & 3 & 12 \\
6 & 2 & 12 \\
7 & 1 & 7 \\
8 & 1 & 8 \\
9 & 2 & 18 \\
12 & 2 & 24 \\
24 & 1 & 24 \\
\hline Total & 45 & 145 \\
\hline
\end{tabular}

Counted as community resources were private physicians, 
private psychiatrists, neighbors, friends, nursing homes and the various social agencies in and out of the city. These contacts were used for various reasons. The physicians and psychiatrists helped in establishing diagnosis before the Home's physician examined the patient. Whe out of city agencies were used in visiting state patients and their families. The nursing homes were approached in relation to patients already residing there.

As mentioned previously, contacts with the referral source would have been greater had the relatives been counted in these totals. In the case of a relative referring, he was classified in the services to relatives rather than in the referral totals.

With a social worker on the staff of the Home who is familiar with policy and procedure, it would seem that much needed time would be saved. New workers coming to Family Service have necessitated an orientation to the Home with each one of these. Ihis problem would not exist if there were a regular social worker at the Home. The contacts between agency staff members would also be eliminated if the social worker were in the Home. It also seems important to note the large number of community resources used. It would seem necessary for the worker to be familiar with the resources in the community, and that she be able to carry through with them in case it is necessary. 
35

TABLE 19

NUMBER OF SERVICES

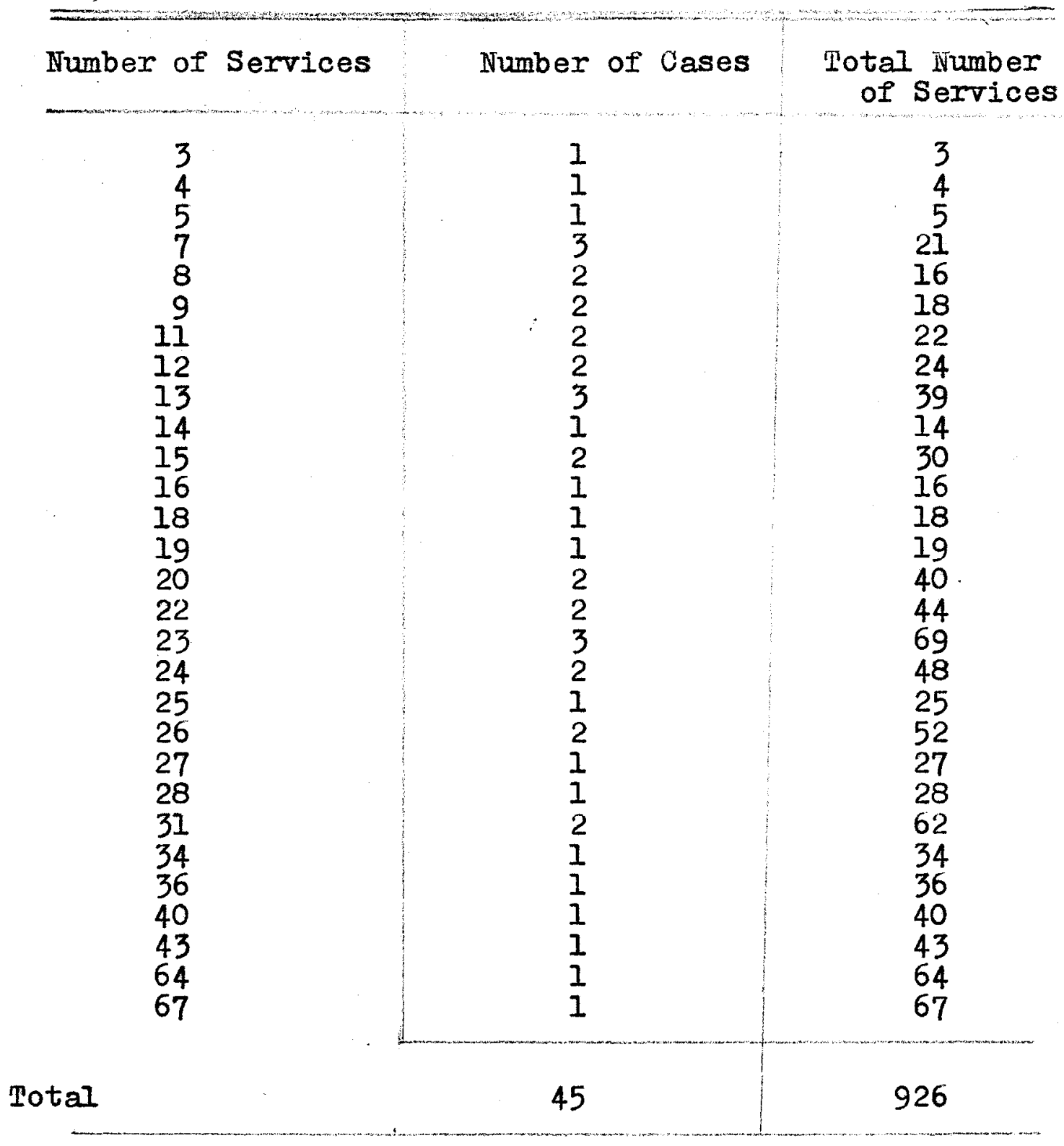


Analysis of Table 19 shows that the average services per case in the Admissions group was 20.5. 'the services to the applicant were given both before and after entrance to the Home. On the majority of cases there were more services before entrance than after entrance. Where were more contacts with the patients who did not want to enter, and who were ambivalent about entrance than there were with the patients who wished to enter. On one state case, there were no contacts before admission but there were thirteen after admission, on the basis of casse work service.

Case work service was continued with three of the applicants' families after the patient entered the Home. Case work services were offered to several of the other families of the patients, but no turtner service was desired by the family. Iwo of these services to the applicant's family consisted of helping a son make arrangements to pay off some debts and services to a daughter in helping her understand and accept her feelings about placement of her father in the Home.

Time between Application and Admission

the largest number of applicants fell into the interim time period of 2 - 3 months. This meant that some sort of care had to be worked out for the applicants dur- 
ing the period they were waiting to gain admission to the Home. In most cases they continued on in their present living arrangements, but in the cases of necessity they went to a nursing home, to relatives other than the ones with whom tney were living when the application was Iirst made, or to some other place where they could receive care for a temporary period. Une applicant's admission was held up to enable him to break himselt from the use of morphine. As has been explained previously, the Hbme does not accept drug addicts. One of the other applicants was longer in gaining admission because he passed up several chances wrien a vacancy occured.

\section{TABLiH 20}

TIME BETWEEN APPIICAIION AND ADMISSION

Time

$1-2$ we eks

3-4 weeks

2-3 months

4-5 months

6-8 months

9-11 months

11-14 months

Total
Total

2

17

19

4

2

1

45

It should be stated that f'amily Service has been 
assisting approximately nine cases referred for service by the Home. 'these cases were not included in this study, as they were already in the Home before Family service took over their work on applications.

\section{TABIE 21}

IIVING ARRANGBIVENII BEIWEEN APPIICAIION AND ADNLSSION

$$
\text { Type }
$$

With Family

With Friends

In Nursing Home

Other Homes

Unknown

Total

\section{Total}

23

3

11

4

4

45

PABLE 22

AGENCY OR PERSONS ILAKING IIVING ARRAIGGEMEN'IS PRIOK IO ADNIISSION rotal

Family Service

1

Family

23

Applicant

6

FSO and Family

3

Family and Applicant

4

Kentucky urippled Childrens Commission

1

Louisville General Hospital

Friends

3

Unknown

Total

45 
CHAPTER III

\section{WITHDRAKALS}




\section{WITHDRAHALS}

During the two year period studied there were found to be 72 withdrawals. Out of these 72 withdrawals only 47 were studied because there were no case records made on 25 or the cases. As soon as Family Service took over the service to the Home contact was made with these 25 cases. Application had been made originally to the Home, in some cases quite some time ago. As soon as these applicants were approached it was learnea that they wisned their name withdrawn from the 1ist. Consequently, there was not enough intormation on these patients to include them in the study. They will only be considered in determining the total number of withdrawals in 1946 and the total number in 1947 .

Out of the total number of 72 cases, in 1946 there were 54 withdrawals. In 1947 there were only 18 withdrawals. Ihis difference is believed to be signiticant. A number of these applicants had not been approached tor quite some time, When the Family Service worker got in touch with them or their tamilies, the applicant either had made other arrangements or had died. After first taking over this service to the Home, Family Service workers spent much time clearing away all of the old wait- 
ing list. When contact was made with an applicant or his family and it was learned that they no longer wanted to gain admission to the Home, this applicant was counted as a witndrawal and his name was taken from the waiting 1ist. Out of the 54 witndrawals in 1946, 26 had made application to the Home prior to this time. This was felt to be effective in the large difference between 1946 and the 1947 withdrawals.

Out of the 47 cases studied over the two year period there were 34 female withdrawals and 13 male withdrawals. This in in accordance with the way the Home is able to take care of more women patients than men.

Age at Time of Withdrawal

The largest group fell in 70-79 years of age. With as large a number as 11 whose ages were not know, it seems difficult to determine if this is accurate; however, in consideration of the ages in the admission group, it may be assumed that the largest grouping would have fallen in the 60-79 year age group.

\section{Marital Status}

The largest group of withdrawals fell in the "Single" group, with the next largest falling in the "Widowed" group. 
This is the same pattern as was noted in the admissions group.

\section{TABLE 23}

AGE OF APPLICAN'LS AT 'LIME OF WITHDRAWAL BY SEX

\begin{tabular}{c|c|c|c}
\hline Age & Male & Female & Total \\
\hline $18-19$ & 1 & - & 1 \\
$20-29$ & - & 2 & 2 \\
$30-39$ & 2 & - & 2 \\
$40-49$ & 2 & 1 & 3 \\
$50-59$ & 1 & 4 & 5 \\
$60-69$ & 2 & 5 & 7 \\
$70-79$ & 3 & 7 & 10 \\
80-89 & 1 & 5 & 6 \\
Unknown & 1 & 10 & 11 \\
Total & 13 & 34 & 47 \\
\hline
\end{tabular}

\section{Residence}

It was believed important to see if there were more State withdrawals than Uity withdrawals. Since it does take longer to secure admission to the Home from the State and County, it was believed that this might prove significant.

In comparison with the admissions there were greater proportions of County and State applicants who witharew. ${ }^{1}$ 
TABLE 24

AGE OF APPLICANT AT TIME OF WITHDRAWAI BY MARITAL STATUS AND SEX

\begin{tabular}{|c|c|c|c|c|c|c|c|c|c|c|c|c|c|c|}
\hline \multirow[t]{2}{*}{ Age } & \multicolumn{2}{|c|}{ Single } & \multicolumn{2}{|c|}{ Married } & \multicolumn{2}{|c|}{ Widowed } & \multicolumn{2}{|c|}{ Dirorced } & \multicolumn{2}{|c|}{ Seperated } & \multicolumn{2}{|c|}{ Unknown } & \multicolumn{2}{|c|}{ Total } \\
\hline & $\mathbf{M}$ & $\mathbf{F}$ & M & $\mathbf{F}$ & $M$ & $F$ & M & $F$ & M & $F$ & M & $F$ & M & $F$ \\
\hline $18-19$ & 1 & - & - & - & -1 & - & - & - & - & - & - & - & 1 & - \\
\hline $20-29$ & - & - & - & 1 & -1 & - & - & - & - & - & -1 & 1 & - & 2 \\
\hline $30-39$ & 2 & - & - & - & - & - & - & - & -1 & - & - & - & 2 & - \\
\hline $40-49$ & 1 & 1 & 1 & - & - & r & - & - & - & - & - & - & 2 & 1 \\
\hline $50-59$ & -1 & - & - & 2 & - & - & 1 & - & - & - & - & 2 & 1 & 4 \\
\hline $60-69$ & 1 & 3 & - & - & - & - & 1 & - & -1 & 1 & 1 & 1 & 2 & 5 \\
\hline $70-79$ & -1 & 3 & 1 & 1 & 1 & 2 & - & 1 & -1 & - & 1 & - & 3 & 7 \\
\hline $80-89$ & -1 & 2 & - & - & 1 & 3 & - & - & - & - & - & - & 2 & 5 \\
\hline Unknown & - & 2 & - & - & 1 & 3 & - & - & - & - & - & 5 & 1 & 10 \\
\hline Total & 5 & 11 & 2 & 4 & 3 & 8 & 2 & 1 & -1 & 1 & 1 & 9 & 13 & 34 \\
\hline
\end{tabular}

TABIE 25

RESIDEMCE OF WITHDRAWALS

Type

City

County

State

Total
Number

29

4

14

47

The ract that it takes a County or State applicant longer to gain admission might have caused this difference. 


\section{4}

Diagnosis

Arthritis, as shown in Table 14, has the largest number of persons who withdrew classified under it. In the chapter on admissions, Table 6 , page 19, shows that paralysis had the largest number, with arthritis being second. The "Unknown" factor of Table 26 might have caused this as there were seven in this group. The other four classifications in the "Other" column was one person with multiple sclerosis, one with amyotrophic lateral sclerosis, one with tuberculosis of the bone and the other with cirrosis of the liver.

\section{TABLE 26}

DIAGNOSIS OF WITHDRAWAIS BY SEX

\begin{tabular}{l|c|c|c}
\hline Diagnosis & Male & Female & Total \\
\hline Arthritis & 2 & 11 & 13 \\
Paralysis & 2 & 5 & 7 \\
Cardian & 2 & 4 & 6 \\
Blind & 1 & 1 & 2 \\
Orthopedic & 2 & 1 & 3 \\
Chorea & - & 2 & 2 \\
Encephalitis & 3 & - & 3 \\
Unknown & 1 & 6 & 7 \\
Other & - & 4 & 4 \\
$\quad$ Total & 13 & 34 & 47
\end{tabular}




\section{Reasons for Withdrawals}

It should be mentioned that a great many of these applications were withdrawn after it was learned just how long it would be before admission to the Home could be gained, although even then some of the applicants wished their names to be kept on the waiting list. When vacancies occurred, these applicants were notified. By this time ten of the applicants had made other arrangements. One had gone to The Iittle Sisters of the Poor and wished to remain there. Another had secured a small apartment and had hired someone to stay with her and take care of her. One of the other applicants went to the Home for the Aged and Infirm and two went to nursing homes. These arrangements were all worked out by the family and the applicant expept for the one who went to the Home for the Aged and Infirm, which was done by Louisville General Hospital and the Division of Old Age Assistance.

The eleven persons who withdrew their own application had various reasons for doing so. One did not want to enter because both he and his wife had applied at the same time and his wife had proved ineligible for care at the Home. Consequently, he lid not want to be separated from his wife. Two applicants withdrew because they, "never wanted to enter in the first place." One had only gone 
through with the application because that was what her family wanted her to do. The other's application had been forced upon her by a minister and some of the neighbors. Another withdrew because his disease did not mean that he could not hold a job and he only needed some place to live; he withdrew his application when he found that the routine of the meals, etc., at the Home conflicted with his working hours. Another witharew her application because she was unable to face an institutional placement. One of the other applicants withdrew because at the time she could enter the Home she had become very ill and did not wish to be moved.

\section{TABLE 27}

REASONS GIVEN FOR WITHDRAWAJ

Reasons

Total

Death

Made other arrangements 10

Own request

11

Family's request

13

Other

Total

Twelve of the other applications were withdrawn at the family's request. The reasons again varied. Iwo of the families recognized senility and mental defectiveness 
in the patients. Realizing that the Home did not accept patients with this accompanying handicap, the applications were withdrawn. Another family was unwilling to turn the applicant's insurance over to the Home, so they withdrew the application. The remainder of the cases were withdrawn for unknown reasons.

\section{Social Agency Contacts}

Table 28 shows that the agency listings were just about the same as the agencies listed in the chapter on admissions.

\section{TABLE 28}

SOCIAI SERVICE EXCHAIVGE INFORMATION BY SEX

\begin{tabular}{c|c|c|c}
\hline & Male & Female & Total \\
Identified & 7 & 13 & 20 \\
Not Identified & 6 & 21 & 27 \\
Total & 13 & 34 & 47 \\
\hline
\end{tabular}

Includes agency registration in Louisville and elsewhere in state.

As shown in the chapter on admissions, the greatest number of applicants were known to social agencies. Since the largest number in both classifications were in the relief agencies, it might seem that financial stress is an underlying and prominent cause for many of the applications. The fact too, that other case working agencies knew the 
applicants before their application was made, might indicate that there were family problems already existing before the need for institutional placement arose. The fact that there were more in the withdrawal group that were not identified might indicate something about the withdrawals. When they are financially able and with no other problems existing, it may be possible that more withdrawals are made. There is a greater probability of their being able to make other arrangements when the are no family or financial problems to complicate their illness.

\section{Precipitating Causes for Application}

Four of the applicants classitied in the "other" column were felt by the relatives to need better care than they were getting in the family home. The applicants too were wondering about the future and thought that living in a Home would be the best thing for them. The relatives could no longer continue care because of varied reasons. In some cases it was due to finances, in others to crowded living conditions, or to the fact that the relatives worked and there was no one to stay with the applicant during the day. 
TABLE 29

PRECIPITAPING CAUSES FOR APPLICAIION BY SEX

\begin{tabular}{|c|c|c|c|}
\hline & Male & Female & Total \\
\hline Housing & 0 & 1 & 1 \\
\hline $\begin{array}{c}\text { Relatives unable to care for } \\
\text { applicant }\end{array}$ & 2 & 8 & 10 \\
\hline $\begin{array}{c}\text { Coulan't continue housekeeping } \\
\text { for self }\end{array}$ & 2 & 4 & 6 \\
\hline Financial & 2 & 4 & 6 \\
\hline Flare-Up in Handicap & 3 & 2 & 5 \\
\hline Accident & - & 2 & 2 \\
\hline Other & 2 & 2 & 4 \\
\hline Unknown & 2 & 11 & 13 \\
\hline Total & 13 & 34 & 47 \\
\hline
\end{tabular}

\section{Iiving Arrangements}

Table 30 shows that more of the applicants were living in a family group than in any other manner. Ihis was probably one of the main reasons for so many contacts between the family and the case worker. Included in the "Other" column was one who was staying in a hospital as there was no other place for her to go.

Difficulties frequently arose when the applicant needed an immediate placement at the Home because this was not always possible, especially when the patient lived out of the 
city. Iists of nursing homes were submitted to the families of the applicants, but this often did not meet the problem. Nursing homes are often so expensive that the family is unable to meet this added expense. When there is a fairly good income in the home, the applicant is not eligible for the Home for the Aged and Infirm. This means that King's Daughters Home is about the only resource for patients in this category. When the waiting period is of any long duration this means that the family or the applicant has to undergo financial stress.

\section{TABLE 30}

IIVING ARRANGEMEINIS

Applicant

Alone

With Family

With Friends

In Nursing Home

Other

Unknown

Total
Total

5

28

1

3

1

9

47

Attituded about Entrance to the Home

There were more applicants who did not want to enter in the withdrawal group than there were in the admissions 
51

group. This was probably one of the underlying reasons for the witharawal even though in some instances the reason was indioated in some other way. Since there ware 12 in the group who did not wish to enter, it can be assumed that there were several in the group of "Unknowns" who did not want to enter.

\section{TABLE 31}

APTITUDE OF APPLICANT ABOUT ENTRANCE TO THE HOME

Attitude

Wished to enter

Did not wish to enter

Ambivalent

Other

Unknown

Total
Total

10

12

2

1

22

47

Table 32, in reference to the attitudes of relatives, shows a contrast between the admission group and the withdrawal group. By far the majority of the relatives in the admission group were in favor of the applicant entering the Home.

Referral Source

The agencies making the referrals were American Red 
Cross, Louisville General Hospital, and one case was already active with Family Service for another problem when the need for institutional placement came up. Again, however, the source of referral came for the largest part through relatives.

\section{TABLE 32}

REIATIVES' ATPITUDES ABOUT APPIICANT ENYERIIVG THE HOME

Attitudes

Favorable

Guilt Reactions

Ambivalent

Not in favor

Uninterested

No relatives

Uniknown

Total
Number

14

4

6

2

1

3

17

47

Number of Services on the Cases

Tables 34 and 39 show a relatively low number of services for forty-six cases. However, some of these applications were made as far back as 1944 and 1945. By the time the Family Service worker approached them there were some who could not even be located. ${ }^{1}$ This is one of the reasons for there being so many unknowns in all the tables of this grouping.

1 Family Service Correspondence to applicant's who applied before 1946 . 
53

TABLE 33

REFERRAI SOURCE

Source

Relative

Friend

Agency

Minister

Doctor

Self

Total
Number

19

7

7

5

3

6

47

TABLE 34

SERVICE BY FAMLIY SERVICE TO APPLICANT

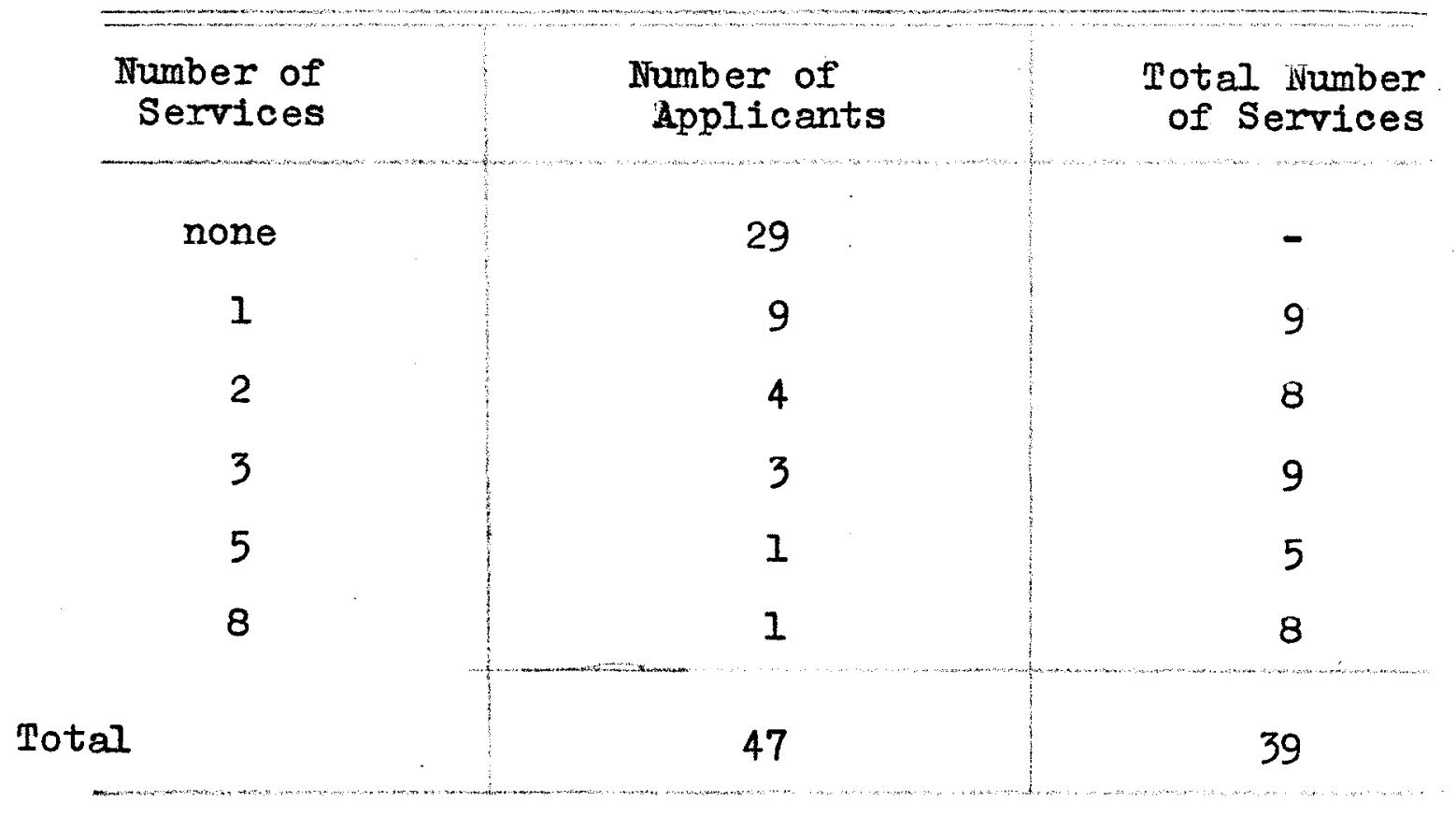


TABIE 35

SERVICES BY FAMILY SERVICE TO RELAIIIVES

\begin{tabular}{c|c|c}
\hline Number of Services & Number of Cases & Total Services \\
\hline none & 18 & - \\
1 & 5 & 5 \\
2 & 5 & 10 \\
3 & 4 & 12 \\
4 & 3 & 12 \\
5 & 5 & 25 \\
6 & 1 & 6 \\
7 & 1 & 7 \\
8 & 2 & 16 \\
9 & 1 & 9 \\
12 & 1 & 12 \\
14 & 1 & 128 \\
Total & 47 &
\end{tabular}

TABLE 36

CONTACTS BY FAMIIY SERVICE WITH REFERRAL*

\begin{tabular}{|c|c|c|}
\hline Number of Services & Number of Cases & Total Services \\
\hline none & 28 & - \\
\hline 1 & 4 & 4 \\
\hline 2 & 3 & 6 \\
\hline 3 & 4 & 12 \\
\hline 4 & 2 & 8 \\
\hline 5 & 5 & 25 \\
\hline 1 & 6 & 6 \\
\hline Total & 47 & 61 \\
\hline
\end{tabular}

* Contacts with relatives who were referrals are not included. 
55

TABLE 37

CONTAC'LS BY FAMILY SERVICE WITH HOME

\begin{tabular}{c|c|c}
\hline $\begin{array}{c}\text { Contacts by Family } \\
\text { Service with Home }\end{array}$ & Number of Cases & Total Contacts \\
\hline none & 28 & - \\
1 & 4 & 4 \\
2 & 6 & 12 \\
3 & 4 & 12 \\
4 & 2 & 8 \\
6 & 2 & 12 \\
7 & 1 & 7 \\
\hline
\end{tabular}

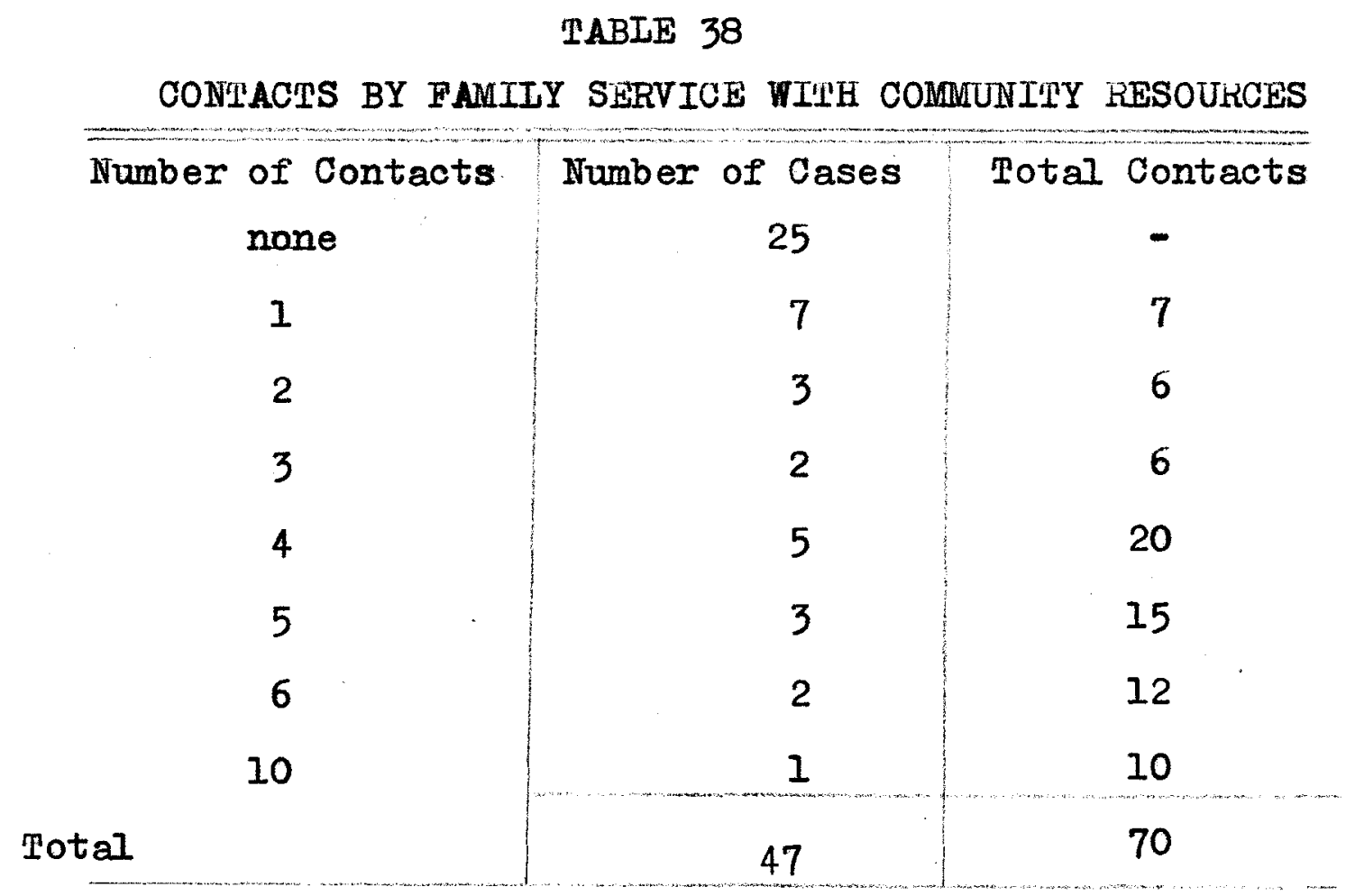

The community resources used were the same that were 
56

shown in Table 17, page 32, They were used also in the same respect as they were in the admissions group.

\section{TABLE 39}

NUMBER OF SERVICES

\begin{tabular}{|c|c|c|}
\hline Number of Services & Number of Cases & Total Services \\
\hline 1 & 3 & 3 \\
\hline 2 & 4 & 8 \\
\hline 3 & 5 & 15 \\
\hline 4 & 4 & 16 \\
\hline 5 & 7 & 35 \\
\hline 6 & 2 & 12 \\
\hline 7 & 3 & 21 \\
\hline 8 & 1 & 8 \\
\hline 10 & 2 & 20 \\
\hline 11 & 2 & 22 \\
\hline 12 & 2 & 24 \\
\hline 14 & 3 & 42 \\
\hline 15 & 3 & 45 \\
\hline 16 & 1 & 16 \\
\hline 17 & 1 & 17 \\
\hline 18 & 2 & 36 \\
\hline 20 & 2 & 40 \\
\hline Total & 47 & 380 \\
\hline
\end{tabular}


Relative to the contacts between the case workers witnin Family Service, the number was quite low with the withdrawal group. There were only nine cases on which there were any contacts. With five of these there was one contact, with three there were two contacts, and with one there were eight contacts.

The average services per case in the withdrawal group was 8.1 , showing fewer services for the witharawals than the admissions.

Two of the cases within this group were already active with W'amily Service for other case work services, at the time the application was made. In two of the cases services were continued with the family after the applicant's name was withdrawn. Case work services were continued with one of the applicants after the withdrawal of his name. Case work services were oftered in three of the other cases but were refused. 
CHAPTER IV

REFUSAIS 


\section{REFUSATS}

During the two year period there were found to be 33 refusals. By refusal is meant those applicants who were found ineligible for care at the Home. Out of these 33 cases only 31 . of them were studied, because on two of the applicants no case record was made. Consequently, there is very little information on them.

Out of the 31 refusals there were a total of 21 females and 10 males. As before the females outnumbered the males. Fifteen of the total number were found ineligible in 1946 with the remaining 16 in 1947. These findings differ from those in the admissions and withdrawal group. Their largest number fell in the first year, the withdrawal group having 39 more in 1946 than in 1947. One factor believed to have some influence on these findings was the fact that a larger number in the admissions and withdrawals had applied for admission prior to 1946. Twenty-six in the withdrawal group had applied prior to that time, all in the admission group and only 4 in the refusal group.

Age of Applicant at time of Refusal

Table 40 shows that the largest number for the refusals fell in the 70-79 years age group with the 60-69 
years group having the next largest number. The applicants who were found ineligible for care were on about the same age level with those who were admitted.

TABLE 40

AGE OF APPLICANT AT TIME OF RHEUSAL BY SEX

\begin{tabular}{r|c|c|c|}
\hline \multicolumn{1}{c|}{ Age } & Male & Female & I'otal \\
\hline $30-39$ & 2 & - & 2 \\
$40-49$ & 1 & - & 1 \\
$50-59$ & - & 1 & 1 \\
$60-69$ & 2 & 7 & 9 \\
$70-79$ & 2 & 9 & 11 \\
$80-89$ & 3 & 4 & 7 \\
Total & 10 & 21 & 31 \\
\hline
\end{tabular}

TABLE 41

MARIIAI STATUS

Status

Single

Widowed

Married

Divorced

Other

Total
Number

11

12

6

1

1

31

Table 41 shows that the widowed and single seem to outnumber the other groups. 
61

Residence.

Table 42 shows that among the refusals the City residents have the largest number. Ihis has held true for each of the different groups studied.

PABLE 42

RESIDENCE

Number

City

County

State

Iotal
21

2

8

31

Reasons Applicants were found Ineligible for Care

There are various diseases which cause applicants to be made ineligible for care at the Home. These diseases are epilepsy, diabetes, cancer and senile psychosis. The Home cannot accept persons with epilepsy or diabetes because of the drug which has to be administered regularly with epileptics and diabetics. The Home does not have a sufficient amount of nursing staff to administer these necessities; another reason for the refusal of diabetics is due to the constant management and attention needed by them. The amount of freedom which the other patients have might be jeopardized if senile patients were accepted. 
When a patient in the home develops senility, it is necessary for him to be removed from the Home at once. This sometimes arouses a lot of feeling in the relatives for they cannot consider committing the patient to a mental institution and yet they are unable to care for the patient themselves. Here, too, is an excellent time for a social worker to give help to the family in seeing the need for placement of the patient in an institution set up for the care of patients with a mental iliness.

Other applicants are refused admission due to incontinence and the fact that they need too much nursing care. Again the Home is unwilling to accept the applicant in this category because they require more nursing care than the Home can give. They feel that these applicants could receive better care in another type of institution or nursing home. Persons who are mentally handicapped are not accepted either for this reason. Persons addicted to drugs and those whose disease is not incurable are ineligible for care at the Home. If the drag addict can arrive at the point where the drug is no longer needed, he then becomes eligible for care at the Home.

In the study made on the 31 cases each of the above were present. One applicant was refused by the Admissions Committee because on a previous admission to the Home he had given indication of not being able to adjust and had 
left the Home. However, as shown in Table 41, it seems that most persons were proved ineligible due to the medical diagnosis.

\section{TABLE 43}

REASONS APPIICANT WAS FOUND INEIIGIBLE FOR CARE

Reanons

Senility

Disease not Incurable

Mentally Handicapped

Needed too great Nursing Care

Psychotic \& Psycho-Neurotic

Cancer

Drug Adiction

other

Total
Total

12

3

4

3

2

2

2

3

31

By far the largest number found inelligible was in the senility group. Included in the "Other" column was one applicant with diabetes, one with epilepsy and one who had left King's Daughters Home at one time voluntarily prior to this application. When an applicant is refused admission to the Home it takes the work of a skilled case worker to handle this with the applicant and his family. The person working with these people has to be able to accept hostility and resentment and needs skill to help the applicant and family work it through. Part- 
64

icularly when an applicant has been refused due to senility or any other mental illness, it is quite hard for the family to accept it. The worker should be conscious of what the family is going through. Along with this skill the worker should have a knowledge of the community's resources that might be used. Plans have to be made. for the applicant and because he is proved ineligible at the Home does not relieve the worker of the responsibility of being able to help the family made other arrangements. If he is not eligible there, it is then the worker's responsibility to help him locate a place where he will be eligible. When there is no resource for this person, it is the worker's responsiblitty to see that the community is informed of the need which it is not meeting.

The largest number of diagnoses for refusals fell in the paralytic group (10), the next in orthopedic conditions (7), arthritis (4), sensory defects (3), cardian conditions (4), and "Other" (4). Those included in the "Other" group was one diabetic, one with anemia, one with only the diagnosis of senility, and one with arrested tuberculosis. Arrested tuberculosis is not considered by the Home to be an incurable disease. Neither is anemial an incurable disease. One of those grouped in the orthopedic conditions was felt to be curable as her broken hip would heal. 


\title{
Social Agency Contacts
}

As in the admissions group there were more applicants who were refused known to Social and Health Agencies than were unknown. Practically the same agencies were listed. The only difference found was a listing by Waverly Hills Clinic, and the Kentucky Pauper-Idiot Pension.

\author{
TABLE 49 \\ REFUSALS \\ IDENTIFIED BY SOCIAL EXCHAINGE
}

Number

Identified

Not Identified

14

Total

31

Precipitating Causes for Application

The largest number in the classes of precipitating causes for the application was found under the grouping of relatives being unable to care for the patients, as shown in Table 45. The reasons the relatives could not continue care varied as they did in the study of the Admissions group. Financial reasons were again in second place. By "outside pressure" is meant that some one or several persons within the community see the importance of the applicant going into the Home, but the applicant 
66.

himself can see no reason for entering. This was also the precipitating cause for one of the patients in the admissions group.

\section{TABLE 45}

PRECIPITATING CAUSE FOR APPLICATION BY SEX

\begin{tabular}{c|c|c|c}
\hline Cause & Male & Female & Number \\
\hline $\begin{array}{c}\text { Financial } \\
\text { applicant }\end{array}$ & 3 & 5 & 8 \\
Relatives unable to care for & 2 & 8 & 10 \\
Outside pressure & - & 1 & 1 \\
Flare-up in Handicap & - & 3 & 3 \\
Accident & 1 & - & 1 \\
Couldn't Continue house- \\
keeping for Self \\
Other \\
Total
\end{tabular}

\section{Living Arrangements}

It seems that the living arrangements of all applicants who were fefused were for the most part with their family as a part of a family group. Out of the six patients who were living in nursing homes, there were five of them who were being supported by their family, so again the family was greatly tied up with the making of the application. The one other applicant who was living in a nursing home 
was paying for his own care. One of the two classified in the "Other" column was staying at Waverly Hills Sanatorium until some other care could be arranged. The other applicant was in the Home for the Aged and Infirm; it was feit that the King's Daughters Home would be a better place for him because of their vocational rehabilitation program.

\section{TABIE 46}

IIVING ARRANGEMENTS

Type

With Family

With Friends

Alone

In Nursing Home

Other

Total
Number

18

1

4

6

2

31

\section{Attitudes about Entrance To Home}

The majority of the applicants in the group of refusals wanted to enter the Home. However, there were a few who did not want to enter and who were ambivalent about it, as shown in Pable 47.

Two of those whose attitudes were unknown however, were too disoriented to say how they felt about going to the Home. These two were later proved ineligible due to 
senility. The applicant who saw no other way out felt herself to be a terrific burden to her family and consequently was willing to go to the Home because she did not know what else to do.

\section{TABLE 47}

APPLICANTS' ATTITUDES ABOUT ENTRANCE TO THE HONE

\section{Attitudes}

Wanted to enter

Did not want to enter

Ambivalent

Saw no other way out

Unknown

Total
Number

14

5

2

1

9

31

The majority of the relatives were affirmative about the applicant being placed in the Home, as shown in Table 48. They recognized it as a good plan and thought it the best thing for the applicant. Two of the relatives were found to be disinterested in regard to making any arrangements for the applicant. Just as long as they were not asked to keep the applicant or to help make any arrangements, they were agreeable to whatever was arranged. Another family wanted the applicant to go to the Home, but apparently were not too much in favor of it, for they were 
unable to give up the applicant's savings to the Home. Five of the applicants had no relatives.

TABLE 48

ATPITUDES ON THE PART OF REIATIVES IN REGARD TO THE APPIICANT ENTERING THE HOME

Attitade

Favorable

Guilt Reactions

Ambivalent

Disinterested

No Relatives

Unknown

Total
Number

20

1

1

2

5

2

31

\section{Referral Source}

As with the other groups studied the greatest source of referrals for the refusals came through relatives. Other sources of referrals were through friends, doctors, ministers and social agencies as well as one self referral.

Included in the "Other" column was one self application, one referred by a minister, and one referred by the head of a nursing home where the applicant was staying.

\section{Number of Services}

There were quite a number of persons in the refusal 
group with whom there were no contacts by Family Service workers. The majority of the persons were either living in the state or outside of Iouisville. The number of contacts with the applicant himself were not as high in this group as they were in the admissions and withdrawal group. Since the applicant was found ineligible for admission, the agency concentrated on contacts with relatives and community resources to see what kind of care was best to consider for the applicant. Contacts again consisted of visits, telephone calls, letters and office interviews.

\section{TABLE 49}

SOURCE OF APPIICATION

$\begin{array}{lc}\text { Source } & \text { Total } \\ \text { Relatives } & 14 \\ \text { Agency } & 6 \\ \text { Friends } & 5 \\ \text { Doctor } & 3 \\ \text { Other } & 3 \\ \quad \text { Total } & 31\end{array}$

There were a large number of cases on which there were no services to relatives. Hive of these had no relatives with whom contact could be made. Four of them lived out in the state and the relatives were not approached. 
There was only one applicant who lived in the city for whom contact was not made with the relatives.

\section{TABIE 50}

SERVICES GIVEN BY FAMILY SERVICE ORGANIZATION TO APPIICANT

\begin{tabular}{c|c|c}
\hline Number of Services & Number of Cases & $\begin{array}{r}\text { Total Number } \\
\text { of Services }\end{array}$ \\
none & 11 & - \\
1 & 13 & 13 \\
2 & 4 & 8 \\
3 & 2 & 6 \\
4 & 1 & 4 \\
Total & 31 & 31 \\
\hline
\end{tabular}

The services to the relatives consisted first of all in securing significant information about the applicant and in determining whether entrance to the Home was really wanted by the applicant and his family. The other points which have been brought out so far in the study were also secured at this time. After the applicant was found ineligible for care at the Home, where it was possible, contacts were continued with the family until some suitable arragements could be made. Three of the families were helped to see the necessity of committing the patient to an institution for the mentally ill. When the family 
did not know the procedure for this, the worker at Family service gave them the necessary information and helped them to proceed with this plan. In other cases the best plan seemed to be nursing home care at which time lists of nursing homes were submitted to the applicant's family.

TABLE 51

SERVICES TO RELATIVES

\begin{tabular}{c|c|c} 
Number of Services & Number of Cases & Total Services \\
\hline none & 10 & - \\
4 & 2 & 8 \\
5 & 2 & 10 \\
6 & 2 & 12 \\
7 & 2 & 14 \\
8 & 2 & 16 \\
9 & 1 & 9 \\
10 & 2 & 20 \\
11 & 4 & 44 \\
14 & 1 & 14 \\
15 & 2 & 30 \\
17 & 1 & 17 \\
& 31 & 194 \\
\hline
\end{tabular}

In some cases where the applicant was not receiving old age assistance, the family was helped to make application 
for the grant. The family thought they would be able to continue care of the patient with this added income in the home. In other cases where old age assistance was already active, the family was directed to their assistance worker to see about placement of the patient in the Home for the Aged and Infirm.

\section{TABLE 52}

THE CONTACTS BY FAMILY SERVICE WITH THE REFERRAI SOURCE

Number of Contacts none

1

2

3

4

5

6

8

Total
Number of Cases $15^{* * *}$

3

3

3

2

2

1

1

31
Total Contacts

3

6

9

8

10

6

8

50

* Contacts with relatives who were referrals are not included.

14 of this number had relatives as the referral.

Out of the thirty-one applicants who were ineligible for care at the Home, there were only two cases in which 
direct hostility was shown toward the agency. In one of these cases there was a conflicting diagnosis on the part of the family physician and the Home's physician. For this reason the family felt quite strongly toward the Home and Family Service, and were unable to follow through with any additional plans. In one of the other cases where the applicant had no relatived, the worker tried to make plans through the applicant's friends. These friends would have nothing to do with Family Service and after the refusal took no interest in making other plans for the applicant.

Family Service worked with the minister of the applicant who had made the referral, and the applicant was moved to a nursing home where she received care. Contacts with the referral as shown in Table 52 were used in making plans for the applicant and for other reasons. When the applicant was found ineligible for care at the Home, the referring person was usually notified, and the reason for the refusal was explained to him.

The contacts. shown in Table 53 were carried on with the Home in relation to the report given by the case worker to the admissions committee, with the Home's physician in regard to his examination of the patient, with the matron of the Home and with the head of the finance committee 
in regard to what the applicant would be able to pay the Home for his upkeep. The one patient on which there were ten contacts with the Home lived in the county. There was no one to examine her there, so she was brought to the Home for an examination. After the examination by the Home's physician, she was found to be senile, so it was necessary for her to leave the Home.

\section{TABLE 53}

CONTACTS BY 'FAMILY SERVICE WIYH THE HOME

\begin{tabular}{c|c|c}
\hline Number of Contacts & Number of Cases & Total Contacts \\
\hline none & 2 & - \\
1 & 4 & 4 \\
2 & 7 & 14 \\
3 & 4 & 12 \\
4 & 4 & 16 \\
5 & 4 & 20 \\
6 & 2 & 12 \\
7 & 2 & 14 \\
8 & 1 & 8 \\
Total & 1 & 10 \\
\hline
\end{tabular}

The contacts with community resources were quite numerous in the Refusal Group. One reason for this was in relation to making some suitable arrangements for the 
applicant. The resources most frequently used were the Municipal Bureau of Social Service, the Division of Old Age Assistance, Iouisville General Hospital, nursing homes, and private physicians.

\section{TABLE 54}

CONTACTS BY FAMIIY SERVICE WITH COMNUNITY RisSOURCES

\begin{tabular}{c|c|c}
\hline Number of Contacts & Number of Cases & Total Contacts \\
none & 5 & - \\
1 & 1 & 1 \\
2 & 6 & 12 \\
3 & 1 & 3 \\
4 & 1 & 4 \\
5 & 3 & 15 \\
6 & 3 & 18 \\
7 & 3 & 21 \\
8 & 3 & 24 \\
10 & 3 & 30 \\
11 & 1 & 11 \\
20 & 1 & 20 \\
\hline Total & 31 & 159
\end{tabular}

The contacts between agency staff members were those between the individual worker on the case and the worker at the agency in ahorge of all the King's Daughters Home 
applications. These were usually about names on the waiting list and how long it would be before an applicant could enter the Home.

\section{TABIE 55}

CONTACTS BETWEEN AGENCY STAFF MEMBERS

\begin{tabular}{c|c|c|} 
Number of Contacts & Number of Cases & Total Contacts \\
none & 16 & - \\
1 & 6 & 6 \\
2 & 4 & 8 \\
3 & 3 & 9 \\
4 & 1 & 4 \\
5 & 1 & 5 \\
Total & 31 & 32 \\
\hline
\end{tabular}

The total number of contacts per case were not quite as high with this group as they were with the admissions, but they were much higher than the withdrawal group. The difference between the admission group and the refusal group was quite small. It would seem that the refusal group was given practically as many services as was the admission group. The data in Table 56 shows that the average number of contacts per case was 18.2. 
78

TABLE 56

THE NUMBER OF SERVICES

\begin{tabular}{|c|c|c|}
\hline Number of Services & Number of Cases & Total Services \\
\hline 3 & 2 & 6 \\
\hline 7 & 1 & 7 \\
\hline 8 & 1 & 8 \\
\hline 9 & 2 & 18 \\
\hline 10 & 2 & 20 \\
\hline 12 & $\therefore 1$ & 12 \\
\hline 14 & 1 & 14 \\
\hline 15 & 2 & 30 \\
\hline 16 & 2 & 32 \\
\hline 17 & 1 & 17 \\
\hline 18 & 1 & 18 \\
\hline 21 & 1 & 21 \\
\hline 22 & 2 & 44 \\
\hline 23 & 1 & 23 \\
\hline 24 & 2 & 48 \\
\hline 25 & 1 & 25 \\
\hline 26 & 2 & 32 \\
\hline 27 & 1 & 27 \\
\hline 28 & 1 & 28 \\
\hline 29 & 1 & 29 \\
\hline 30 & 1 & 30 \\
\hline 34 & 1 & 34 \\
\hline 42 & 1 & 42 \\
\hline , & 31 & 565 \\
\hline
\end{tabular}


CHAPTER V

THE WAITING IIST 


\section{CHAPIER V}

\section{THE WAITING IIST}

As has been mentioned previously a waiting list has been kept by Family Service during the two year period. This waiting list was kept in three parts. There was a city waiting list, a county waiting list, and a state waiting list. The reasons for this again were due to the large contribution of funds submitted by the Iouisville Community Chest. For this reason it was felt that the city applicants should have first choice with the county and the state groups following, the latter having the least preference. When a state applicant enters, it is at the time that there is no one waiting on the other two lists. These lists are again broken down to a male and female waiting list. Even though there are city women on the list, if there is no city or county men on the list, a state male may enter. This is due to the number of men and women patients in the Home. Ho female can come into the Home in a malesplace, or vice versa, due to the physical set up of the Home.

Again it was found that the females far outnumbered the males in wishing entrance to the Home. Even though there are more beds for females than males in the Home, the demands for admission is far greater from women than 
81

from men.

At the end of this study the watiting list consisted of 17 applicants--15 of which were female and 2 of which were male. Three of the females were on the city waiting list. All of the other 14 were on the state waiting list.

$\begin{array}{cc}\text { TABLE } 57 \\ \text { AgE OF APPLICANTS } \\ \text { IIST } \\ 17-19 & \text { Number } \\ 20-29 & 2 \\ 30-39 & 1 \\ 40-49 & 3 \\ 50-59 & 2 \\ 60-69 & - \\ 70-79 & 2 \\ 80-89 & 3 \\ 90-100 & - \\ \text { Unknown } & 1 \\ \text { Total } & 3 \\ \end{array}$

Age of Applicants

Though the waiting list was comparitvely small in comparison with the number of admissions and withdrawals, 
82

slightly larger numbers show up in the 30-39 and 70-79 years groups. However, in proportion with the other two groups the number under the 30-39 years group seems high for the waiting list. If and when these persons gain admission, they would probably be quite interested in occupational therapy.

PABLE 58

MARITAT STATUS OF APPIICANTS ON WAITING IIST

Status

Single

Widowed

Married

Unknown

Total
Number

Marital Status

The proportion of single persons in the waiting list seems to be quite high. One factor which probably had some influence on this factor was the fact that there was a larger number of younger persons in this group.

\section{Diagnosis}

Table 59 shows diagnosis by sex and age for persons 
83

on the waiting 1ist. As was done before, the disability that was felt to be most crippling was chosen for this classification. Considered in the "Other" column was one patient with progressive muscular dystrophy, one with Parkinsonian's disease, and one whose disease was unknown. The Orthopedic group has the highest number, with paralysis having only one less.

\section{TABLE 59}

DIAGMOSIS OF APPLICANT'S ON WAITING IIST BY SEX AND AGE

\begin{tabular}{|c|c|c|c|c|c|c|c|c|c|c|}
\hline \multirow[t]{2}{*}{ Age } & \multicolumn{2}{|c|}{ Arthritis } & \multicolumn{2}{|c|}{ Paralysis } & \multicolumn{2}{|c|}{ Orthopedic } & \multicolumn{2}{|c|}{ Other } & \multicolumn{2}{|c|}{ Total } \\
\hline & M & $F$ & $\mathbf{M}$ & $F$ & $M$ & $F$ & $\mathbb{M}$ & $F$ & $\mathbb{M}$ & $\mathbf{F}$ \\
\hline $17-19$ & - & - & 1 & 1 & -1 & - & 1 & - & 2 & 1 \\
\hline $20-39$ & - & - & - & 1 & - & - & - & - & - & 1 \\
\hline $30-39$ & - & 2 & - & 1 & - & - & - & - & - & 3 \\
\hline $40-49$ & - & 1 & - & 1 & - & - & - & - & - & 2 \\
\hline $50-59$ & - & - & - & - & - & - & - & - & - & - \\
\hline $60-69$ & - & - & - & 1 & - & 1 & - & - & - & 2 \\
\hline $70-79$ & - & - & - & - & 1 & - & - & 2 & 1 & 3 \\
\hline $80--89$ & - & - & - & - & - & - & - & - & - & - \\
\hline $90-99$ & - & - & - & - & - & 1 & - & - & - & 1 \\
\hline other & - & - & - & - & - & 3 & - & - & - & 3 \\
\hline Total & - & 3 & - & 5 & 1 & 5 & 1 & 2 & 23 & 15 \\
\hline
\end{tabular}

Residence

Out of the 17 persons on the waiting list only three 
84

of them were city residents. The remaining 14 lived in the state outside of the city. This ratio has been quite oonsistent through the two year period studied. It would indicate that it does take longer for applicants in the state outside of the city to gain admission than for the city residents. Three of the applicants had applied to the Home for admission as far back as 1945. When Family Service made their yearly check in 1947 these applicants still wished their names kept on the list. The majority of them had remained with their relatives and planned to continue this arrangement until they could gain admission to the Home. Even though they were informed that it might be a year or longer before they could gain admission, they still preferred to keep their name on the list. Many of them really had no other place to go other than King's Daughters Home, for there are not many resources for chronically ill persons in the state of Kentucky.

\section{Social Agency Contacts}

Out of the 17 applicants in this group only four of them were known to social agencies. I'wo of these were city applicants. It is felt that the number is smaller in this group than in the others due to the fact that so many more are state applicants. It is difficult to know if these persons are known to social agencies when they 
85

do not live in Louisville or Jefferson County and are cleared through the Soclal Service Exchange.

\begin{tabular}{lc}
\multicolumn{2}{c}{ TABLE 60} \\
KEFERRAI SOURCE OF WAITING IIST \\
Number \\
Family & 7 \\
Self & 2 \\
Doctor & 1 \\
Agency & 7 \\
$\quad$ Total & 17 \\
Source of Application &
\end{tabular}

In comparison with the other groups studied, there seem to be more referrals in this group than in any other. This may be due to the fact that more agencies are becoming aware of King's Daughters Home for Incurables, and are using it more than they used to do. These referrals were made through the Department of Welfare in Frankfort, through Red Cross agencies in the state, the Municipal Bureau of Social Service, and the Kentucky Crippled Childrens Commission. One of the referrals came through the state President of the King's Daughters Order.

Since it would be quite some time before most of these 
persons on the waiting list could gain admission to the Home a complete study is not made. This is done for various reasons. If the complete study were made at the time of application for the state applicants, sometimes it is a year or longer before they can gain admission. In this length of time there can be many things which can happen to change what is learned at the time of application. Consequently, only enough information is secured to know that the applicant is eligible for further study, and this is completed at the time a vacancy occurs.

Since this is the usual procedure for those on the waiting list, there was not enough information secured for study around the factors studied in the other groups. Also the number of services was much smaller in proportion to the other groups. There were only a total of eighty-nine contacts for these seventeen cases. Of course, it must be remembered that these cases will each have more services before the applicant is admitted to the Home.

The waiting list seems to be a very important thing to keep. Not only does it keep the order in which each applicant shall enter the Home, but it also gives the person keeping it an idea of how many people are waiting. Then when anotherapplication is made, she had this information and can estimate as closely as possible about the length of time it will be before the applicant can 
gain admission. If it is going to be an extremely long period the family or the person making application should know this in order to make plans accordingly. During the period that Family Service Organization handled the services to King's Daughters Home for Incurables two supervisors had charge of this. list. These two kept in close contact with the Home and attended the monthly Admissions Committee meeting at the Home. The individual case workers working with the applicant also attended these meetings from time to time. When emergencies kept the supervisors in charge of the waiting list away, they were represented by another member of the Family Service Supervisory staff. It was with one of these two that the individual case workers consulted from time to time on the different cases. It seemed very important for the agency to have one person in charge of all the Home's admissions, and through this person, a co-ordination which would probably not have been obtained otherwise was usually present. If a social worker was working within the Home, there would be no need for a person in this role, for the worker would be in constant contact with the Home and the members of the Admissions Committee. This would cut down considerably on time spent under the present arrangements. There would be no time taken in phoning and visiting the Home 
88

in regard to various questions arising. Otherwise with the group of students who do carry cases at framily Service changing from year to year and too, with the taking of new workers from time to time, it necessitates a new group working with the Home. These workers in turn have to learn all about the Home.

Precipitating Causes for Application

The "Other" category in Table 61 represents one application of an individual who badly needed care in a Home due to her phyeical condition and one applicant who was living in such an acute home situation that she needed to get awaj.

\section{TABTE 61}

PRECIPITATING CAUSES FOR APPLICATION

Cause

Number

Relatives can't continue care 10

Accident 2

Unknown 3

Other 2

Total 17

Living Arrangements

The largest group of applicants, as shown in Table 62, 
89

were making their home with relatives and living as a part of a family group. In the "other" category, was one applicant who was staying in a hospital and three whose living arrangements were unknown.

TABLE 62

IIVING ARRANGEMENTS

Arrangement Number

With relatives. 11

In nursing home 2

Other 4

Total 17

Attitudes about Entrance to the Home

Since not too much study has been done on those applicants on the waiting list not much can be concluded from the findings in relation to the applicants' attitudes about entrance to the Home. The same thing holds for the attitudes of the relatives. In Table 63, the unknown factor was much higher than the known as was to be expected since no attempt was made to individualize those applicants at this early date.

Services on the Waiting Iist

As was mentioned previously there was a total of 59 
90

contacts in this group. There was a total of 10 services to the applicant, 24 services to relatives in relation to the applicant, 24 contacts with the referral, 18 contacts with the Home, 15 with community resources, and 2 between staff members. Again the relatives have had the highest number of contacts with the agency.

TABLE 63

APPLICANTS ATTITUDES TOWARD ENTERING THE HOME

Attitude

Want to enter

Unknown

Total
Number

6

11

17

\section{TABLE 64}

ATTITUDE OF REIATIVES TOWARD APPLICANT ENTERING HOME

Attitude

Favorable

Unknown

No relatives

Total number

8

8

1

17 
CHAPTER VI

CONCLUSIONS AND RECOMENDATIONS 


\section{CHAPPER VI}

CONCLUSIONS AND RECOMMENDATIONS

\section{Conclusions}

1. The majority of applicants who applied for care at the King's Daughters Home during the two Jear period were in the 60 - 79 years age group.

2. The female applications outnumbered the male applications two to one.

3. The marital status of the majority of applicants was either widowed or single.

4. The city applications doubled the state applications, with the latter being almost six times as great as the county applications.

5. The proportion was about the same for those Identified and not identified by the Social Service bixchange.

6. The majority of applicants were suffering from some form of paralysis while the next largest group had a diagnosis of arthritis, orthopedic conditions, or cardiac conditions, respectively.

7. The precipitating cause, following the medical 
diagnosis was, first, because relatives were unable to care for the applicant and second, because of financial stress of the patient.

8. By far the majority of applicants when making application were living with relatives as a part of a family group.

9. The majority of applicants wished to enter the Home. However, there were some who did not want to enter and some who expressed ambivalent feelings about entrance.

10. By far the largest number of relatives were affirmative about the applicants entering the Home. However, there were some who expressed guilt, ambivalence, disinterest and disfavor.

11. The largest group of referrals came through relatives while the next largest number came through agencies, friends, and self applications, respectively.

12. There was a total of 1960 services rendered in the 140 cases. Two hundred of these were rendered directly to the applicant; 386 of the services were given indirectly to the applicant through the use of community resources; and 223 through the reterral 


\section{4}

source. There were 610 services to the relatives of the applicant; the majority of these were centered around the applicants going to the Home and to his adjustment after entrance, and the others were direct service to the relatives. There were 439 contacts with the Home and 102 between agency staff members.

\section{Recommendations}

Since at this time the Family Service Organization is attempting to evaluate the results of its two year demonstration period, and is in the process of trying to decide whether their out-post services should be continued or whether another plan should be devised, and in consideration of the conclusions of this study indicating that a great deal of valuable time of the case working staff is lost because of it being an out-post service, the following recommendations are offered:

1. That one full time medical social worker be employed by the Home to interview the applicants and their families.

A. A social worker would help the families understand the meaning of placement to the patient and let them $\mathrm{know}$ the importance of their visiting with the patient in order that he will not feel he is completely forgotten.

B. In case of a long waiting period before ad- 
mission, the social worker could help the family and applicant to make temporary arrangements elsewhere.

c. In case a person is found ineligible for care at the Home, a social worker could interpret this to the family and suggest other resources for help with the problem.

D. A social worker could help the applicants and their families to understand and alarify their feelings about entrance to the Home. After the patient enters the Home, the social worker could serve as a link between patient and the home left behind.

2. That the medical social worker also have the responsibility for case work services to those patients already under the care of the Home.

A. A social worker working within the Home could be available to the patients when any problems arise.

B. When problems come up which do not fall within the function of the social worker in the Home, she could make arrangements for this service to be met elsewhere.

C. A medical social worker has a background in the understanding of physical illness and what it can mean to the patient. She is well equipped for working with patients suffering from a chronic illness.

3. That the medical social worker accept the responsibility for working with the matron of the Home, the occupational therapist of the Home, and with outside resources for rehabilitation according to the individual need of the patient.

4. That the medical social worker should work with the members of the Board of the Home in services rendered by board members to individual patients. This would mo- 
bilize and coordinate all services being carried on for the patients. 
APPENDIX 


\section{APPENDIX}

Schedule Used in Study

1. IDENTIFYING INFORMATION
A. Name
C. Sex
D. Age
B. Case
F. Residence
E. Marital Status
G. Religion

2. SOCIAI SERVICE EXCHANGE INFORMATION
A. Known
Agency or Agencies
B. Unknown

3. DISPOSITION OF CASE
A. Acceptance
B. Refusal
1. Mental Condition
2. Cancer
3. Epilepsy
4. Disease not Incurable
5. Needs too great nursing care
6. Incontinence
7. Other

c. Withdrawals

1. Made other arrangements

2. Death

3. At own request

4. At Families request

5. Other

4. DIAGHOSIS

5. PRECIPITAPING CAUSES FOR APPIICATION

A. Housing

B. Pinancial

C. Relatives can no longer continue care

D. Outside Pressure

E. Flare up of Handicap

F. Accident

a. Car

B. Fall

c. Other

G. Can no longer continue housekeeping for self

H. Other 
6. IIVING ARRANGEMENTS
A. Alone
B. With Family
C. With Friends
D. In nursing Home

$$
\begin{aligned}
& \text { a. Financed by self } \\
& \text { b. Financed by other } \\
& \text { 1. Relative } \\
& \text { 2. Old Age Assistance } \\
& \text { 3. Other }
\end{aligned}
$$

E. Other

7. FEELIHGS ABOUT ENTRANCE TO THE HOME

A. On the part of the applicant

$$
\begin{aligned}
& \text { a. Wants to enter } \\
& \text { b. Does not want to enter } \\
& \text { c. Ambivalent } \\
& \text { d. Sees no other way out } \\
& \text { e. Other }
\end{aligned}
$$

B. On the part of the family of applicant

a. Favorable

b. Guilt over institutional placement

$$
\text { of a relative }
$$

c. Ambivalent

d. Disfaror

e. Disinterest

f. Other

8. PROCEDURES OF FAMILY SERVICE ORGANIZATIONS SERVICE

A. Source of Intake

$$
\begin{aligned}
& \text { a. Self application } \\
& \text { b. Individual } \\
& \text { c. 1. Relative } \\
& \text { 2. Friend } \\
& \text { 3. Doctor } \\
& \text { 4. Minister } \\
& \text { 5. Other }
\end{aligned}
$$

B. Services to Applicant

C. Services to Relative in connection with applicant

D. Services to relatives with their own problems

E. Contacts with the referral source 
F. Contacts with the Home

G. Contacts with community resources

H. Contacts between Agency staff members

I. Total number of contacts

J. Case work service given to family

1. after acceptance of applicant

2. after refusal

3. after withdrawal

4. pending admittance

K. Case work service offered but refused

9. INTERTM OF CARE BETWEEN APPIICATION AND DISPOSITION OF CASE
A. Length of period
B. Kind of care worked out
C. By whom
1. Family Service
2. Family
3. Applicant
4. Other

10. REMARKS 
BIBIIOGRAPHY 


\section{BIBLIOGRAPHY}

\section{Articles}

Bartlett, Harriett. "Emotional Elements in Illness: Responsibilities of the Medical Social Worker," The Family, April, 1940, pp. 39-47.

"Social Case Nork: The Central Function of a Medical Social Service Department", The Family, December, 1938, pp. 247-51.

Cockerill, Eleanor. "Intake Process in a Department of Yedical Social Service," The Family, October, 1940, pp. 188-94.

Conner, Leora I. "Outposts of Service", Highlights, Hovember, 1946, pp. 109-12.

Margolis, H. M. "Care of the Patient with Theumatoid Arthrit1s," The Family, January, 1945, pp. 323-31.

Fitzsimmons, Margaret. "Treatment of Problems of Dependency Related to Permanent Physical Handicap", The Family, January, 1943, pp. 329-36.

Hertzman, Jeanette. "Case work in the Psychosomatic Approach," The Family, December, 1946, pp. 299-307.

Hathan, Cynthia Rice. "Social Service to Plastic Surgery Cases," The Family, March, 1945, pp. 9-15.

"Service to Amputees," The Family, February, 1945, pp. 363-66.

Rapp, Sahra S. "Boarding Care for the Aged Sick," The Family, July, 1946, pp. 192-96.

Rohret, Cecilia Healy. "Problems in Convalescent Care," The Family, December, 1944, pp. 309-12.

Rothstein, Mildred R. "Individual Personality Factors in IlIness," The Family, December, 1946, pp. 313-20.

Schless, Bessie G. "Social Case Work Services to the Arthritic.Patient," The Family, January, 1945, pp. 331-37. 
103

Yocum, Susan Folks. "Case Work with the Physically III, "The Family, November, 1939, pp. 216-31.

Unpublished Material

American Association of Medical Social Workers, Report of the Joint Committee on Administration of social Service Departments in Hospitals, March, 1947 